Boston University School of Law Scholarly Commons at Boston University School of Law

Faculty Scholarship

2008

\title{
The New Death of Contract: Creeping Corporate Fiduciary Duties for Creditors
}

Frederick Tung

Boston Univeristy School of Law

Follow this and additional works at: https://scholarship.law.bu.edu/faculty_scholarship

Part of the Law Commons

\section{Recommended Citation}

Frederick Tung, The New Death of Contract: Creeping Corporate Fiduciary Duties for Creditors, 57 Emory Law Journal 809 (2008). Available at: https://scholarship.law.bu.edu/faculty_scholarship/563

This Article is brought to you for free and open access by Scholarly Commons at Boston University School of Law. It has been accepted for inclusion in Faculty Scholarship by an authorized administrator of Scholarly Commons at Boston University School of Law. For more information, please contact lawlessa@bu.edu. 


\title{
Emory University School of Law
}

\section{Public Law \& Legal Theory Research Paper Series}

Research Paper No. 07-29

\author{
Law \& Economics Research Paper Series \\ Research Paper No. 07-24
}

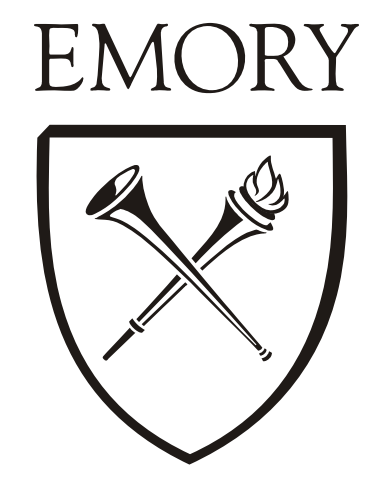

THE NEW DEATH OF CONTRACT: CREEPING CORPORATE FIDUCIARY DUTIES FOR CREDITORS

Frederick Tung

This paper can be downloaded without charge from:

The Social Science Research Network Electronic Paper Collection:

http://ssrn.com/abstract=1031242 


\title{
THE NEW DEATH OF CONTRACT: CREEPING CORPORATE FIDUCIARY DUTIES FOR CREDITORS
}

\author{
Frederick Tung
}

This Article identifies a worrisome trend in corporate law and scholarship. Across seemingly unrelated issue areas, courts and scholars have lost faith in private corporate bargains. They invite judicial intervention into private contract, proposing to expand fiduciary duties beyond their traditional shareholder-centered focus to protect non-shareholder claimants from managerial opportunism. When conflict between claimant classes becomes acute, managers pursuing shareholder value may make inefficient investments that benefit shareholders but harm other claimants and the firm generally. I argue that claimants' private contracts with the firm are superior to expanded duty for constraining this opportunism.

I focus on one specific conflict-the conflict between shareholders and creditors. Existing doctrine already works a shift in fiduciary duties to creditors when this conflict becomes acute-when a firm becomes insolvent. Scholars propose to expand on current doctrine to include more creditors more of the time. I argue that both existing doctrine and its proposed expansions suffer fatal theoretical infirmities. The chief failing is that the accepted hypothetical bargain analysis from which corporate fiduciary duty derives cannot justify current doctrine or expansion proposals. Expanded duty to creditors is also costly compared to private contract.

I propose an approach that I call contract primacy. Shareholder primacy should remain the default rule. Private contracting should be effective to curb manager opportunism. Additional legal constraints are costly and unnecessary. Sophisticated creditors typically negotiate elaborate covenant protections by the time a firm is in distress, often to the benefit of other

\footnotetext{
* Professor of Law, Emory University School of Law. A.B. 1983, Cornell; J.D. 1987, Harvard Law School. E-mail: fred.tung@law.emory.edu. Web: http://www.law.emory.edu/faculty/faculty-profiles/ftung. html. For thoughtful comments on earlier drafts of this Article, I owe special thanks to Bobby Ahdieh, David Bederman, Bill Carney, Jesse Fried, Michael Kang, Jonathan Lipson, Larry Ribstein, Robert Schapiro, Albert Yoon, and workshop participants at the Canadian Law and Economics Association 2007 Annual Meeting, the Midwestern Law and Economics Association 2007 Annual Meeting, and the 2007 Eugene P. and Delia S. Murphy Conference on Corporate Law at Fordham Law School.
} 
creditors, who implicitly delegate monitoring responsibilities to the low-cost monitor. A creditor may even negotiate for control of the firm, displacing shareholder primacy. Against the current doctrine and conventional wisdom, courts should vindicate these contracts for creditor primacy without insisting on the firm's insolvency. Current doctrine should be abandoned, and proposals for further expansion of fiduciary duty for creditors should be rejected. 


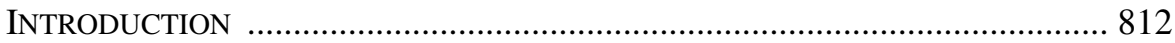

I. EXPANDING FIDUCIARY DUTIES …………………...................... 818

A. Fiduciary Duties for Incomplete Shareholder Contracting ........ 819

B. The Conventional Case for Including Creditors ....................... 820

C. The Case for Further Expansion of Fiduciary Duties to

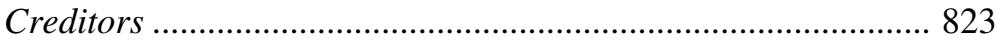

D. The Countertrend: Against Expanded Duty .............................. 825

II. HYPOTHETICAL BARGAINS FOR CREDITORS ………......................... 827

A. Creditor Heterogeneity .......................................................... 829

1. Security Interests and Residual Claimant Status ................. 831

2. Nonfinancial Interests ...................................................... 832

3. Contract Protections and Renegotiation Prospects ............. 833

B. Creditor Interdependence: The Theory of Delegated

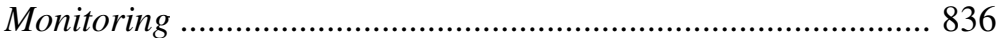

1. Banks as Delegated Monitors ............................................. 836

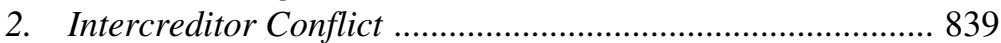

C. The Creditors' Hypothetical Bargain? ..................................... 840

1. Not All Credit Contracts Have Gaps ..................................... 841

2. $\quad$ Not All Creditors Would Agree to Creditor Duty ................. 842

D. Specific Problems for Hypothetical FVM Bargains ................... 843

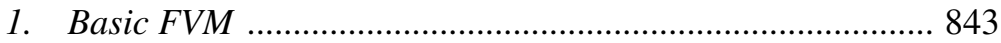

2. FVM-Plus-Performance-Creditors .................................................. 846

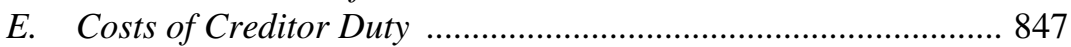

1. Increasing Litigation and Caution Costs ............................. 848

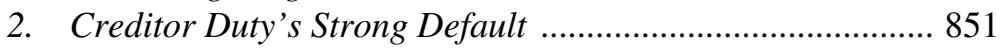

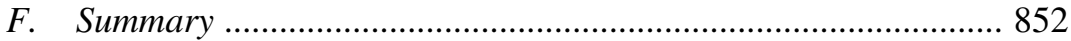

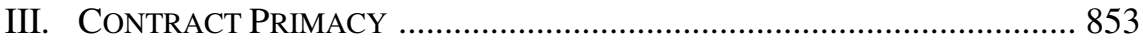

A. The Shareholder Primacy Default ............................................ 854

B. Contracting for Primacy …………………………................... 856

C. Actual Contracts ......................................................................... 858

1. The Corporate Governance Arrangement in Credit

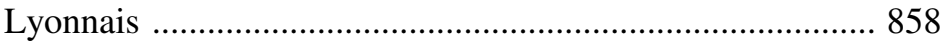

2. Blackmore Partners ............................................................... 861

D. Bargain Should Trump Duty: Abolishing Duty-Shifting

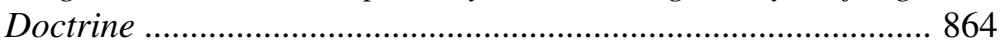

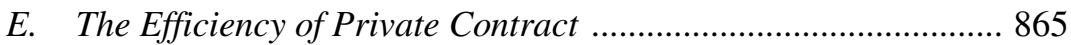

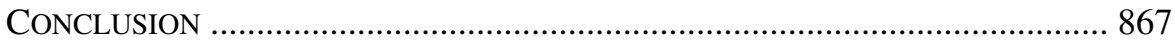




\section{INTRODUCTION}

Over thirty years ago, Grant Gilmore foretold the death of contract. ${ }^{1} \mathrm{He}$ gave name to the trend toward expanding legal enforcement of obligations, based not on formal bargain but on broad notions of reliance and duty. Since his famous prognostication, the province for duty-based legal intervention in contract has further expanded. Contract law has moved away from text in favor of context. ${ }^{2}$

The trend has also begun to permeate corporate law and corporate scholarship. Across seemingly unrelated issue areas, courts and scholars have lost faith in private corporate bargains. They propose expanded duties, inviting judicial intervention into private contract. Interventionists generally fear the traditional shareholder-centered focus of corporate fiduciary duty. Unswerving loyalty to shareholders might cause corporate managers to pursue inefficient investments to benefit shareholders at other claimants' expense. Potential victims include banks and bondholders, ${ }^{3}$ all parties owed contractual performance by the firm, ${ }^{4}$ startup-company founders and early-stage investors, ${ }^{5}$ and investors in derivatives and hybrid securities, ${ }^{6}$ among others. Their contracts with the firm are assumed to be deficient in constraining managerial opportunism. New duties are required.

Despite their sundry applications, proposals for expanded fiduciary dutywhat I refer to as "Expanded Duty"-share a common approach, a commonality that has so far gone unnoticed. They spot a conflict between classes of corporate claimants-typically common shareholders versus some

1 Grant Gilmore, The Death of CONTRACt (1974).

2 See Robert E. Scott, The Death of Contract Law, 54 U. ToRonTo L.J. 369, 371-77 (2004).

3 See infra Part I.B-C.

4 See infra Part I.C.

5 See Jesse M. Fried \& Mira Ganor, Agency Costs of Venture Capitalist Control in Startups, 81 N.Y.U. L. REV. 967, 1020-22 (2006). Fried and Ganor propose expanded fiduciaries duties in a related direction. See $i d$. Instead of insufficient private constraints on managers' wealth maximizing for common shareholders, Fried and Ganor see insufficient private constraints on venture capitalist preferred shareholders in control of startup company boards. See id. at 1025.

6 See Henry T.C. Hu, New Financial Products, the Modern Process of Financial Innovation, and the Puzzle of Shareholder Welfare, 69 TEX. L. REV. 1273 passim (1991) (noting conflicts among different classes of common stock and difficulties for fiduciary duty rules from financial innovation); Frank Partnoy, Financial Innovation in Corporate Law, 31 J. CORP. L. 799, 810-11 (2006) (discussing indeterminacy of residual claimant resulting from financial innovation). 
other class. ${ }^{7}$ Noting the possibility of perverse investment incentives for shareholder-focused managers when interclass conflict becomes acute, proponents prescribe inclusion of both classes as joint beneficiaries of managerial fiduciary duties. ${ }^{8}$ Under these duties, managers are forbidden from favoring either class unless the benefit to the one exceeds the harm to the other. ${ }^{9}$ In effect, this new rule mandates Kaldor-Hicks-efficient investment. ${ }^{10}$ Like Gilmore's elegy for contract, duty trumps bargain here. Managers' behavior is subjected to ex post standards-based judicial assessment, secondguessing private contract.

This betokened death of contract in corporate law runs counter to the contractarian theory of the corporation that has come to dominate corporate law thinking over the past two decades. In this conception, the shareholder contract is but one among many, and duties to shareholders are conceived in contractarian terms. The duties merely fill the gaps in the incompletely specified relationship between shareholders and firm managers. ${ }^{11}$ Given the myriad complex decisions that firm managers must make to run the company, an explicit contract between shareholders and firm management to govern their relationship would be hopelessly incomplete. Instead, corporate fiduciary duty supplies a general gap-filling standard: firm managers should run the firm for shareholders' benefit. This traditional shareholder primacy norm has long

7 See Alon Chaver \& Jesse M. Fried, Managers' Fiduciary Duty upon the Firm's Insolvency: Accounting for Performance Creditors, 55 VAND. L. REV. 1813, 1815 (2002) (financial claimants versus contracting parties with the firm); Fried \& Ganor, supra note 5, passim (preferred versus common shareholders); Thomas A. Smith, The Efficient Norm for Corporate Law: A Neotraditional Interpretation of Fiduciary Duty, 98 Mich. L. REv. 214, 217-19 (1999) (common shareholders versus creditors). Other scholars note similar conflicts but do not prescribe specific new duties. See Hu, supra note 6, at 1281-82 (conflicts across multiple classes of equity); Partnoy, supra note 6, passim (common shareholders versus holders of hybrid securities and derivatives).

8 Fried and Ganor's Expanded Duty proposal for preferred-common conflicts in this vein takes the form of a recommendation for charter modification, as opposed to a legal mandate. Fried \& Ganor, supra note 5, at $1020-23$.

9 Chaver \& Fried, supra note 7, at 1843; Fried \& Ganor, supra note 5, at 1023; Smith, supra note 7, at 243. $\mathrm{Hu}$ and Partnoy also question the continuing viability of the simple shareholder primacy norm in the face of financial innovation. See Hu, supra note 6, at 1286; Partnoy, supra note 6, at 809.

10 A Kaldor-Hicks-efficient transaction is one in which the winners could compensate the losers, whether or not they actually do. RICHARD A. POSNER, ECONOMIC ANALYSIS OF LAW 13 (6th ed. 2003); see also Matthew D. Adler \& Eric A. Posner, New Foundations of Cost-Benefit Analysis 10-11 (2006).

11 Frank H. Easterbrook \& Daniel R. Fischel, The Economic Structure of Corporate Law 92 (1991) [hereinafter EASTERBRoOK \& Fischel, ECONOMIC STRUCTURE OF CORPORATE LAW]. Trust, fairness, and equity are all quaint concepts but beside the point. "Fiduciary duties are not special duties; they have no moral footing; they are the same sort of obligations, derived and enforced in the same way, as other contractual undertakings." Frank H. Easterbrook \& Daniel R. Fischel, Contract and Fiduciary Duty, 36 J. L. \& ECON. 425, 427 (1993) (footnote omitted) [hereinafter Easterbrook \& Fischel, Contract and Fiduciary Duty]. 
been dominant among courts and commentators. ${ }^{12}$ But Expanded Duty revisits the fundamental question: for whom should corporate managers manage?

Expanded Duty is problematic on several fronts. The chief theoretical infirmity is that the hypothetical bargain framework from which corporate fiduciary duty derives cannot support its proposed expansions. In addition, public duty is costly compared to private bargain. In this Article, I seek to reassert the primacy of shareholder primacy and the primacy of contract. Imagined contracts should not trump real ones. ${ }^{13}$ Private bargain is preferable to public duty. I first attack the basis of the duty. I then propose an approach that I call contract primacy.

In this Article, I focus on Expanded Duty specifically in the context of shareholder-creditor conflict, perhaps the most important corporate conflict for assessing Expanded Duty. This debt-equity conflict has absorbed the attention of corporate and finance scholars for at least three decades, ${ }^{14}$ and expanded fiduciary duty for creditors is the original Expanded Duty. Longstanding doctrine already operates to curb shareholder primacy when conflict is thought to be at its most severe-when the firm is insolvent. At that point, fiduciary duties shift from shareholders to creditors. ${ }^{15}$ Courts and scholars have offered extensions of this insolvency-triggered duty-shifting doctrine. The famous Credit Lyonnais decision extended solicitude to creditors-into the "vicinity" of insolvency. ${ }^{16}$ Even as the firm approaches insolvency, that court asserted, creditors ought to be included with shareholders as beneficiaries of fiduciary duties. $^{17}$ Following the lead of Credit Lyonnais, scholars have proposed

12 See infra Part I.A.

13 Easterbrook \& Fischel, Contract Fiduciary Duty, supra note 11, at 427 ("Actual contracts always prevail over implied ones.").

14 Jensen and Meckling's seminal paper offered the original agency model for the debt-equity conflict. See generally Michael C. Jensen \& William H. Meckling, Theory of the Firm: Managerial Behavior, Agency Costs and Ownership Structure, 3 J. Fin. ECON. 305 (1976).

15 See infra Part I.B. While this doctrine traditionally does not require a shared duty with shareholders, we can conceive of it as a special case of Creditor Duty. Upon insolvency, the theory goes, shifting duties solely to creditors is efficient, since at that point, they become the firm's residual claimants. The implicitthough conceptually questionable-assumption is that, upon insolvency, common shares become worthless.

16 See Credit Lyonnais Bank Nederland, N.V. v. Pathe Commc'ns Corp., No. 12,1240, 17 Del J. CoRP. L. 1099, 1991 WL 277613 (Del. Ch. 1991).

17 In the vicinity of insolvency, shareholders and creditors belong to a "community of interests" deserving of managers' duties. Id. at 1155-56 n.55. This "vicinity of insolvency" duty was recently rejected by the Delaware Supreme Court. N. Am. Catholic Educ. Programming Found. v. Gheewalla, 930 A.2d 92, 101 (Del. 2007); see also infra Part I.B. The traditional duty shift upon actual insolvency, however, remains intact. See Prod. Res. Group, L.L.C. v. NCT Group, Inc., 863 A.2d 772, 790-91 (Del. Ch. 2004) ("When a 
further extensions of creditor-protective duty. ${ }^{18}$ Throughout the Article, I refer collectively to existing duty-shifting doctrine and proposals for its expansion as "Creditor Duty." The issues implicated by Creditor Duty are representative of Expanded Duty generally. The costs, benefits, and theoretical questions relating to Expanded Duty are all on display. ${ }^{19}$

As a putative hypothetical bargain, Creditor Duty suffers from both substantive and process objections. The general substantive objection is that the content of any putative Creditor Duty bargain is implausible. Efficiencydemanding duties are neat in theory and facially unobjectionable, but parties negotiate over distribution, not joint efficiency. ${ }^{20}$ The absence of explicit efficiency requirements in any of the actual contracts that Creditor Duty implicates is telling. Moreover, creditors have varying contract rights and risk preferences. Those that enjoy extensive contract protections are unlikely to favor duties for weaker creditors that might affect relative distributions. Creditor Duty ignores intercreditor conflict. It paints all creditors as one undifferentiated unitary mass of unsecured creditors. Only with this blind eye can an imagined Creditor Duty bargain be conjured. But once intercreditor conflict is acknowledged, a hypothetical Creditor Duty bargain becomes farfetched. ${ }^{21}$

Hypothetical Creditor Duty bargains also suffer a process objection: widespread contract failure is unlikely. Concededly, creditors vary in their contract protections. Even absent transaction costs, however, credit contracts would vary as they now do. The theory of delegated monitoring explains why. ${ }^{22} \mathrm{~A}$ borrower and its multiple lenders share an interest in minimizing

firm has reached the point of insolvency, it is settled that under Delaware law, the firm's directors are said to owe fiduciary duties to the company's creditors.").

18 See infra Part I.C.

19 Moreover, the debt-equity scenario may offer the strongest case for Expanded Duty. As noted, the existing duty-shifting doctrine is one of long standing, upon which scholars attempt to build an even broader duty. Any policy advantage of public duty over private bargain may be at its greatest in this context. Creditors vary in their contracting and monitoring abilities. Some are sophisticated; some concededly are not. Remediable contracting failure would show up here, if anywhere. In other Expanded Duty areas of interestconcerning relations with startup company founders or investors in hybrid securities, for example — contracting failure may be much less a concern. Given the potentially strong case for Expanded Duty in this creditor context, the general case for Expanded Duty suffers if Creditor Duty turns out to be weak.

20 See John C. Coffee, Jr., The Mandatory/Enabling Balance in Corporate Law: An Essay on the Judicial Role, 89 COLUM. L. REV. 1618, 1623 (1989) ("Nothing that we know about the real world suggests that individuals are actually so risk neutral as to behave in a fashion that is indifferent to the distribution of gains and losses.").

21 See infra Part II.C.

22 See infra Part II.B. 
overall monitoring costs. The parties may therefore willingly delegate the task to the lowest-cost monitor, with other creditors free-riding on the efforts of the monitoring creditor. So variation among credit contracts hardly suggests widespread contracting failure. Not all credit contracts have gaps. ${ }^{23}$ Any mandatory, blanket gap-filling rule for all credit contracts is therefore inapt.

Finally, Creditor Duty is costly. A shared duty among conflicting claimants increases litigation risks and costs. This complicates corporate decisionmaking. Boards may forego efficient but potentially contentious transactions. Creditor Duty may be difficult to contract around. Its costs are likely to dwarf the costs of inefficient investment that actual contracts might fail to prevent.

With Gilmore's contracts, plausible tradeoffs may exist between bargain and duty. Given the vast array of contexts in which contract law must operate, ${ }^{24}$ standards-based ex post judicial intervention may elucidate parties' intent in a way that bargain formalism cannot. ${ }^{25}$ Corporate credit contracts, however, are different. Parties' relative sophistication and delegated monitoring among creditors suggest the incongruity of a general license for courts to rewrite corporate credit contracts ex post. ${ }^{26}$ While the threat of

23 At least obligational gaps are unlikely. These are the sorts of gaps that lawyers worry about. Economists worry about contingent incompleteness. See infra note 143 and accompanying text.

24 See generally Michael J. TREBILCOCK, The Limits of Freedom of Contract 241-68 (1993).

25 See 3 Arthur L. Corbin, Corbin On Contracts $\S 538$ (1963) (advocating the use of contextual evidence to determine parties' subjective intent).

26 On this point, Baird and Rasmussen have found:

Today's investors allocate control rights among themselves through elaborate and sophisticated contracts that already anticipate financial distress. . . . As long as the parties whose interests are at stake have already decided among themselves what will happen in bad states of the world, nothing is to be gained by second-guessing them.

Douglas G. Baird \& Robert K. Rasmussen, The End of Bankruptcy, 55 STAN. L. REV. 751,755 (2002); see also Alan Schwartz \& Robert E. Scott, Contract Theory and the Limits of Contract Law, 113 YALE L.J. 541 (2003). Schwartz and Scott partition the universe of contracts into four categories based on whether the buyer, seller, or both is an individual or a firm. They point out that for contracts other than firm-to-firm contracts, one or more bodies of law besides contract law typically govern, making contract law secondary or superfluous. With firm-to-firm contracts as the main focus of contract law, they argue that the singular purpose for contract law should be to facilitate efficient trading. See id. at 544-45.

Contracting parties in the close corporation context may be less sophisticated. Corporate law has generally imputed greater fiduciary duties in the close corporation context than for public companies. See, e.g., Donahue v. Rodd Electrotype Co. of New England, Inc., 328 N.E.2d 505 (Mass. 1975) (enunciating equal opportunity rule for close corporation stock repurchases). Consistent with this approach, unsophisticated creditors to close corporations may warrant stronger fiduciary protections than sophisticated commercial creditors to public companies. See, e.g., Geyer v. Ingersoll Publ'ns Co., 621 A.2d 784, 786 (Del. Ch. 1992) 
shareholder-primacy-induced managerial opportunism exists, private contracting provides a tailored response to the problem. ${ }^{27}$

Run-of-the-mill credit contracts limit managers' discretion to favor shareholders. In addition, a creditor may effectively contract for its own primacy, displacing common shareholders as managers' favored constituency. ${ }^{28}$ This contractual revision to shareholder primacy goes against the conventional wisdom that the duty of loyalty is mandatory and noncontractible. ${ }^{29}$ Yet, as I show, courts have approved such private arrangements for creditors. ${ }^{30}$ In so doing, however, courts have been tethered to existing duty-shifting doctrine requiring the firm's insolvency in order to sanction creditor primacy by contract. ${ }^{31}$ Moreover, even if no such contract exists, duty shifting occurs upon insolvency by law. ${ }^{32}$ The doctrine therefore turns out to be overinclusive and underinclusive. It offers rights to creditors who have not contracted for them, and it may impede a creditor from exercising rights for which it has contracted. I argue against the doctrine and in favor of contract. ${ }^{33}$

Under this approach — what I call contract primacy—shareholder primacy should remain the default rule. Private contracting alone should be effective to shift managers' loyalties in favor of creditors. Additional legal constraints are both unnecessary and costly. ${ }^{34}$ Contracting for creditor primacy has gone unrecognized as such in the literature. Identifying this development reinforces the disutility of mandated duties. Creditors can attain primacy without courts. While the primacy of contract generally goes undisputed, the trend toward Expanded Duty suggests that a conscious and explicit reiteration of the idea is useful. I coin contract primacy just as a host of newfangled "primacies"-

(recognizing fiduciary rights in dispute between two former partners of general partnership who later substituted corporate structure for partnership structure).

27 Fried and Ganor's Expanded Duty proposal - to protect common shareholders from venture-capital preferred shareholder opportunism-is somewhat akin to my contractual approach. They argue for private tailoring of charter provisions: firms should be allowed to opt into "tighter" fiduciary restrictions that might enhance firm value. See Fried \& Ganor, supra note 5, at 1020. Actual contracts would seem superior to their approach, however, especially given the hurdles to enforcement of fiduciary duties. See infra notes 166 and accompanying text.

28 For example, creditor designees may dominate the board of directors or firm management. See infra Part III.C.

29 See infra Part III.B.

30 See infra Part III.C.

31 See infra Part III.C.

32 See infra Part I.B.

33 See infra Part III.D.

34 See infra Part II.E. 
"director primacy,",35 “employee primacy,",36 “creditor primacy,", primacy, $" 38$ to name a few-work their way into the corporate law lexicon to challenge or distinguish shareholder primacy. I offer contract primacy as both a rejoinder to Creditor Duty proposals and an invocation for a renaissance for corporate contractualism.

The remainder of the Article proceeds as follows. Part I recounts the trend toward expanding corporate fiduciary duties to include creditors. In Part II, I question the plausibility of a hypothetical Creditor Duty bargain. I also explain the costliness of Creditor Duty. Part III proposes contract primacy. I first justify the shareholder primacy default. I then dispel the overbroad notion that corporate fiduciary duty is mandatory and not contractible. Finally, I explain why actual contracts to curb inefficient investment are superior to Creditor Duty. I then conclude.

\section{EXPANDING FIDUCIARY DUTIES}

Ordinarily, shareholders are the only corporate stakeholders to whom firm managers owe fiduciary duties. Though other groups-creditors and employees, for example-are also interested in the corporation's success, their relations with the corporation are typically formed through and governed primarily by explicit contracts. ${ }^{39}$ These parties are generally expected to protect their interests through their contracts with the firm. This Part describes the trend of expanding fiduciary duties beyond shareholders to include creditors. Part I.A briefly recounts the incomplete contracts approach to corporate fiduciary duties. Part I.B describes the longstanding insolvencybased duty-shifting doctrine. Part I.C details recent scholarly proposals for

35 Stephen M. Bainbridge, Director Primacy: The Means and Ends of Corporate Governance, 97 Nw. U. L. REV. 547, 551 (2003) (rejecting the idea of the board as the agent of shareholders but retaining the shareholder wealth maximization norm).

36 Brett H. McDonnell, Employee Primacy, Or Economics Meets Civic Republicanism at Work (Univ. Minn. Law Sch. Legal Studies Research Paper Series, Paper No. 06-06, 2006), available at http://ssrn.com/ abstract $=878790$ (advocating ultimate employee control over the corporation toward the end of maximizing employee welfare).

37 Jonathan C. Lipson, Directors' Duties to Creditors: Power Imbalance and the Financially Distressed Corporation, 50 UCLA L. REV. 1189, 1224-25 (2003).

38 Steven A. Ramirez, The Special Interest Race to CEO Primacy and the End of Corporate Governance Law, 32 DEL. J. CORP. L. 345 (2007) (decrying CEO “dictatorship”).

39 See William A. Klein, The Modern Business Organization: Bargaining Under Constraints, 91 YALE L.J. 1521, 1531-32 (1982). My analysis excludes tort creditors and other involuntary claimants, whose predicament other commentators have addressed through various proposals. See infra note 87 and accompanying text. 
further expansion of fiduciary duties for creditors. Scholars propose expanding the current doctrine to cover more creditors more of the time. As earlier noted, I refer collectively to these proposals, along with existing duty-shifting doctrine, as Creditor Duty. Finally, in Part I.D, I identify some scholarly pushback opposing Creditor Duty.

\section{A. Fiduciary Duties for Incomplete Shareholder Contracting}

Shareholder primacy demands that managers run the firm with a view to maximizing shareholder wealth. In general, this rule is efficient. The economic justification is straightforward. Common shareholders are ordinarily the firm's residual claimants-they own the claim on the corporation's residual value after all other obligations have been paid. ${ }^{40}$ As residual claimants, shareholders suffer the firm's marginal losses and enjoy its marginal gains, so every decision by the firm's management directly affects shareholder wealth. Shareholders therefore value the benefit of managerial fiduciary duties more highly than other corporate constituents. ${ }^{41}$ Maximizing shareholder value also generally maximizes firm value, which is socially beneficial. So managers should manage the firm with a view to maximizing shareholder value. This shareholder primacy norm harnesses the zest for private wealth maximization to serve the broader goal of social wealth maximization. ${ }^{42}$

According to the standard contractualist view of the corporation, corporate fiduciary duties merely fill the gaps in the incompletely specified relationship between shareholders and firm managers. ${ }^{43}$ Given the range of complex decisions that firm managers must make-and the broad discretion they must exercise-in order to run the business, an explicit contract between shareholders and firm management to govern their relationship would be hopelessly incomplete. Instead, corporate fiduciary duty supplies a general gap-filling standard: firm managers should run the firm for shareholders' benefit. $^{44}$

40 Robert Charles Clark, Corporate LaW 18 (1986).

41 See Frank H. Easterbrook \& Daniel R. Fischel, Voting in Corporate Law, 26 J.L. \& ECON. 395, 403 (1983); see also Jonathan R. Macey, Fiduciary Duties as Residual Claims: Obligations to Nonshareholder Constituencies from a Theory of the Firm Perspective, 84 CORNELL L. REV. 1266, 1273 (1999) [hereinafter Macey, Fiduciary Duties].

42 See EASTERBrooK \& Fischel, ECONOMic Structure of CORPORATE LAW, supra note 11.

43 See id. at 92; Macey, Fiduciary Duties, supra note 41, at 1273; Smith, supra note 7, at 216.

44 EASTERbroOK \& FisCHEL, ECONOMIC STRUCTURE OF CORPORATE LAW, supra note 11, at 92. 


\section{B. The Conventional Case for Including Creditors}

When a firm is insolvent, creditors, rather than shareholders, by definition become the firm's primary residual risk-bearers. ${ }^{45}$ Shareholders have essentially lost their bet on the company, and now creditors suffer the firm's marginal losses. Post-insolvency investments by the firm are in effect gambles with the creditors' money. Managers' fiduciary duties should shift to creditors. Instead of maximizing shareholder wealth, managers should instead look after the interests of creditors when the firm is insolvent. ${ }^{46}$ This insolvency-based duty-shifting approach is fairly settled law in Delaware and other jurisdictions. $^{47}$

With the firm's insolvency, managers would face perverse incentives under a shareholder primacy rule. Limited liability for shareholders means that shareholders enjoy the potentially unlimited upside from a spectacularly risky investment, but downside risk is borne by creditors. Firm managers faithfully pursuing shareholder wealth maximization, therefore, may be tempted to make very risky investments, ${ }^{48}$ since spectacular returns-however unlikely-would inure to the benefit of shareholders, while losses would be borne by creditors. ${ }^{49}$

45 Traditional balance-sheet insolvency means that the value of the firm's liabilities exceeds the value of its assets.

Margaret Blair and Lynn Stout, among others, have pointed out the numerous groups that have residual interests in the firm's financial success. See Margaret M. Blair \& Lynn A. Stout, Director Accountability and the Mediating Role of the Corporate Board, 79 WASH. U. L.Q. 403, 404 (2001) (describing residual interest of creditors, managers, and employees, as well as shareholders).

46 FDIC v. Sea Pines Co., 692 F.2d 973, 976-77 (4th Cir. 1982) (finding that "when the corporation becomes insolvent, the fiduciary duty of the directors shifts from the stockholders to the creditors"); In re W. World Funding, Inc., 52 B.R. 743, 763 (Bankr. D. Nev. 1985) (finding that "when the corporation is insolvent [fiduciary duties] run to creditors”); Prod. Res. Group, L.L.C. v. NCT Group, Inc., 863 A.2d 772, 790-91 (Del. Ch. 2004) (finding that " $[\mathrm{w}]$ hen a firm has reached the point of insolvency . . . the firm's directors are said to owe fiduciary duties to the company's creditors”); Geyer v. Ingersoll Publ'ns Co., 621 A.2d 784, 787 (Del. Ch. 1992) (finding that "insolvency . . . creates fiduciary duties for directors for the benefit of creditors").

47 See Laura Lin, Shift of Fiduciary Duty upon Corporate Insolvency: Proper Scope of Directors' Duty to Creditors, 46 VAND. L. REV. 1485, 1512 \& n.88 (1993) (citing cases).

48 This is the classic problem of asset substitution. Once credit is extended, the creditor is concerned with the riskiness of its borrower's future projects. The borrower may be tempted to substitute higher variance projects for lower variance projects in order to enhance the value of the firm's equity. Clifford W. Smith \& Jerold B. Warner, On Financial Contracting: An Analysis of Bond Covenants, 7 J. Fin. ECON. 117, 118-19 (1979).

49 I abstract from the issue of managerial agency costs and accept for present purposes the assumption, implicit in Creditor Duty proposals and discussion generally, that firm managers are faithful agents, pursuing policies for the benefit of whichever constituencies may be the legal beneficiaries of managerial fiduciary duties. Cf. Stephen M. Bainbridge, Much Ado About Little? Directors' Fiduciary Duties in the Vicinity of Insolvency, 1 J. BUS. \& TECH. L. 335, 358 \& n.113 (2007) (questioning whether managers of a firm in distress will favor creditors); Henry T.C. Hu \& Jay Lawrence Westbrook, Abolition of the Corporate Duty to 
Even investments with negative expected value for the firm would be pursued, as long as there was positive expected value to shareholders. This is the problem of overinvestment. The social objection is not that creditors would lose value, but that these projects destroy firm value. ${ }^{50}$ Creditors stand to lose more than shareholders stand to gain. ${ }^{51}$

Creditors, 107 CoLuM. L. REv. 1321, 1351 (2007) (arguing that managers are excessively risk averse in any event and distress increases their disincentive to take shareholder-optimal risks); Lynn M. LoPucki \& William C. Whitford, Corporate Governance in the Bankruptcy Reorganization of Large, Publicly Held Companies, 141 U. PA. L. REV. 669, 684 (1993) (finding that managers may not necessarily favor either shareholders or creditors).

50 Managers might also underinvest, foregoing efficient investments that would benefit creditors but not shareholders. See Lin, supra note 47, at 1496. Foregoing projects, of course, is a much more difficult transgression to police than overinvestment.

51 Consider an example. Suppose that ABC Corporation is insolvent. It has $\$ 90$ in cash, and it owes $\$ 100$ to bondholders, who are its only creditors. Its managers have two investment options. Option 1 is safe. Option 2 is risky. Each requires investment of the firm's $\$ 90$ in cash, and each has two possible outcomes, a high return and a low return. After an investment option is chosen and the outcome determined, the firm will pay its bondholders, distribute any excess to shareholders, and then dissolve.

For Option 1, the two possible outcomes are:

1. $80 \%$ chance of returning $\$ 110$, and

2. $20 \%$ chance of returning $\$ 85$.

Option 1's expected value to the firm is $\$ 105((80 \%$ x $\$ 110)+(20 \%$ x $\$ 85)$, or $88+17)$. Net of the $\$ 90$ investment, the firm expects a gain of $\$ 15$.

Option 2, the risky investment, also has two possible outcomes:

1. $10 \%$ chance of returning $\$ 290$, and

2. $90 \%$ chance of returning $\$ 10$.

Option 2's expected value to the firm is $\$ 38((10 \% \times \$ 290)+(90 \% \times$ x $\$ 10)$, or $29+9)$. Net of the $\$ 90$ invested, the firm expects a loss of $\$ 52$.

Option 2 is clearly inefficient. It generates an expected loss for the firm, and it makes no sense for the firm to pursue. Option 1 with a positive expected value is worth pursuing.

Now compare the outcomes of the two investments from the separate perspectives of bondholders and shareholders. For Option 1, the high outcome of $\$ 110$ would pay bondholders in full $(\$ 100)$; the low outcome would pay them all of the $\$ 85$ return. Factoring in the probabilities of the two outcomes, Option 1 delivers an expected return to bondholders of $\$ 97((80 \% \times \$ 100)+(20 \% \times \$ 85)$, or $80+17)$. The $\$ 90$ investment in Option 1 is therefore good for the bondholders. It improves their expected return by $\$ 7$, as compared to their pre-investment situation with rights to the $\$ 90$ cash.

Shareholders also stand to gain from Option 1. The high outcome would leave them with $\$ 10$ after paying off bondholders, though the low option would still leave the firm insolvent and therefore leave nothing for shareholders. The expected return to shareholders from Option 1 is $\$ 8(80 \% \times \$ 10)$. So it appears that Option 1 is good for both shareholders and bondholders.

How about Option 2? For bondholders, the high outcome would pay them in full, while the low outcome would pay them only $\$ 10$. Their expected return under Option 2 is $\$ 19((10 \% \times 100)+(90 \% \times \$ 10)$, or $10+9)$. So the $\$ 90$ investment is clearly an undesirable investment from bondholders' perspective.

For shareholders, however, things look better under Option 2. Under the high outcome, shareholders gain $\$ 190$ after bondholders are paid off. Under the low option, shareholders get nothing. Shareholders' expected return under Option 2 is $\$ 19((10 \%$ x 190) + (90\% x 0)).

Summarizing these various outcomes: 
Courts have recognized that these perverse incentives for managers may operate not only at insolvency, but even as the firm nears insolvency. ${ }^{52}$ The closer the firm is to insolvency, the greater the incentive for managers-now likely to be gambling at least in part with creditors' money-to choose risky and possibly even negative expected value investments to maximize shareholder returns. It may be, therefore, that shareholders' primacy should begin to fade even before the firm reaches the point of insolvency. The famous Credit Lyonnais decision identifies a "vicinity of insolvency."

Option 1

\begin{tabular}{|l|l|l|l|}
\hline Probability & $\begin{array}{l}\text { High Outcome } \\
80 \%\end{array}$ & $\begin{array}{l}\text { Low Outcome } \\
20 \%\end{array}$ & Expected Return \\
\hline \hline Return to Firm & 110 & 85 & $\begin{array}{l}\mathbf{1 0 5} \\
(80 \% \times 110)+ \\
(20 \% \times 85)\end{array}$ \\
\hline $\begin{array}{l}\text { Bondholders' } \\
\text { return }\end{array}$ & 100 & 85 & $\begin{array}{l}\mathbf{9 7} \\
(80 \% \times 100)+ \\
(20 \% \times 85)\end{array}$ \\
\hline $\begin{array}{l}\text { Shareholders' } \\
\text { return }\end{array}$ & 10 & 0 & $\begin{array}{l}\mathbf{8} \\
(80 \% \times 10)+ \\
(20 \% \times 0)\end{array}$ \\
\hline
\end{tabular}

Option 2

\begin{tabular}{|l|l|l|l|}
\hline Probability & $\begin{array}{l}\text { High Outcome } \\
10 \%\end{array}$ & $\begin{array}{l}\text { Low Outcome } \\
90 \%\end{array}$ & Expected Return \\
\hline \hline Return to Firm & 290 & 10 & $\begin{array}{l}\mathbf{3 8} \\
(10 \% \times 290)+ \\
(90 \% \times 10)\end{array}$ \\
\hline $\begin{array}{l}\text { Bondholders' } \\
\text { return }\end{array}$ & 100 & 10 & $\begin{array}{l}\mathbf{1 9} \\
(10 \% \times 100)+ \\
(10 \% \times 10)\end{array}$ \\
\hline $\begin{array}{l}\text { Shareholders' } \\
\text { return }\end{array}$ & 190 & 0 & $\begin{array}{l}\mathbf{1 9} \\
(10 \% \times 190)+ \\
(90 \% \times 0)\end{array}$ \\
\hline
\end{tabular}

Notice that under Option 2, the overinvestment, the expected outcome for shareholders is better than under Option 1 ( $\$ 19$ versus $\$ 8$ expected return). But Option 2 reduces the expected value of the firm as well as bondholders' expected return. Managers duty bound to maximize shareholder wealth, however, would choose Option 2 over Option 1. To achieve value for shareholders and return the firm to solvency, managers may be tempted to choose the risky investment. When the firm is insolvent, shareholder primacy causes social welfare and shareholder welfare to diverge.

52 See In re Healthco Int'l, Inc., 208 B.R. 288 (Bankr. D. Mass. 1997) (recognizing perverse incentives for a manager operating while the corporation had "unreasonably small capital" but was not yet insolvent); Credit Lyonnais Bank Nederland, N.V. v. Pathe Commc'ns Corp., No. 12, 1240, 17 DEL. J. CoRP. L. 1099, 1155, 1991 WL 277613 (Del. Ch. 1991) ("[W]here a corporation is operating in the vicinity of insolvency, a board of directors . . . owes its duty to the corporate enterprise.").

53 Credit Lyonnais, 17 DEL. J. CORP. L. at 1155. 
firm reaches that neighborhood, according to the court, managers owe duties not just to shareholders but to the "corporate enterprise." included with shareholders in the "community of interests" to which managers owe fiduciary duties. ${ }^{55}$ While the Delaware Supreme Court recently rejected Credit Lyonnais' zone-of-insolvency expansion of fiduciary duties for creditors, ${ }^{56}$ the conceptual case remains for acknowledging managers' perverse investment incentives even before the point of insolvency. ${ }^{57}$

\section{The Case for Further Expansion of Fiduciary Duties to Creditors}

Scholars have advocated expanding on the insolvency-based duty shifting embodied in existing case law. They point out that shareholder-creditor conflicts are in fact broader than existing doctrine recognizes. Fiduciary duty should be correspondingly expanded.

Tom Smith has argued that the "zone of insolvency" notion may not be a coherent construct. ${ }^{58}$ For Smith, managers governed by shareholder primacy have perverse incentives to make inefficient investments all the time, regardless of the firm's nearness to insolvency. ${ }^{59}$ Big risky bets are increasingly available to firm managers. Bet-the-company projects are not hard to find. What this means is that managers do not have far to search for projects that will maximize shareholder value if successful but will leave the company insolvent if unsuccessful. In other words, the firm's "nearness" to insolvency - the value of its equity, in conventional balance sheet terms-does not affect managers' latitude to make negative expected value bets that are good for shareholders. The only difference between a firm "near" insolvency

\footnotetext{
$54 I d$.

55 Id. at 1155 \& n.55 (suggesting that directors' duties in the vicinity of insolvency should run to the "corporate enterprise," which includes creditors as well as stockholders); see also Prod. Res. Group, L.L.C. v. NCT Group, Inc., 863 A.2d 772, 789-91 (Del. Ch. 2004) (holding that directors' vicinity-of-insolvency duty was to maximize firm value, but upon insolvency, duties run to creditors alone). How managers might balance the competing interests of shareholders and creditors is unclear. See Rutheford B. Campbell, Jr. \& Christopher W. Frost, Managers' Fiduciary Duties in Financially Distressed Corporations: Chaos in Delaware (and Elsewhere), 32 J. CoRP. L. 491, 504 (2007) (discussing possible interpretations of Credit Lyonnais duty); Frederick Tung, Gap Filling in the Zone of Insolvency, 1 J. Bus. \& TECH. L. 607, 623 n.63 (2007).

56 See N. Am. Catholic Educ. Programming Found. v. Gheewalla, 930 A.2d 92 (Del. 2007).

57 Jensen and Meckling showed us long ago, of course, that the agency cost of debt is more nuanced than the typical zone-of-insolvency discussion describes. See Jensen \& Meckling, supra note 14, at 344-45. Insolvency is not some magic event that triggers perverse incentives for managers that do not exist before insolvency. Instead, the agency cost of debt is increasing in the percentage of outside financing comprised of debt versus equity. $I d$.

58 Smith, supra note 7, at 223.

59 Id.
} 
in the conventional sense and one that is not is the size of the bet that would push the firm into insolvency. ${ }^{60}$ From this perspective, every firm is always in the zone of insolvency, and shareholder primacy always leaves managers free to overinvest to the benefit of shareholders. ${ }^{61}$

Rather than setting and shifting fiduciary duties based on the firm's solvency, Smith argues that managers should always strive to maximize the value of all financial claims on the firm. ${ }^{62}$ Smith relies on hypothetical contract analysis to formulate this proposed new fiduciary rule. He notes that shareholders are not the only stakeholders with imperfectly specified contract rights against the corporation. ${ }^{63}$ Creditor contracts are similarly incomplete, albeit perhaps not to the same degree. But rather than conceive of the hypothetical bargain as being among shareholders and creditors-i.e., separate classes of securities - Smith argues that rational investors are the parties among whom the bargain should be constructed. ${ }^{64}$ Smith assumes that all investors are rational and therefore fully diversified. More specifically, they all hold the market portfolio, investing proportionally in the equity and bonds of every issuer to create a "microcosm of all capital assets." "55 This sort of diversified investor would be indifferent to any distributional issues between classes of securities. For Smith, a hypothetical bargain among these fully diversified investors would not specify shareholder wealth maximization as its fundamental goal. Instead, each investor would rather that managers maximize the value of the sum of all financial claims on the company. This financial value maximization (FVM) should be the general charge for directors, and not shareholder value maximization. ${ }^{66}$

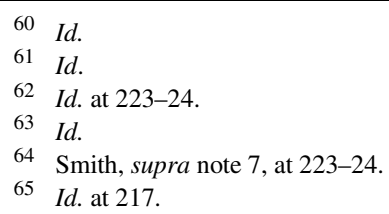

[R]ational investors . . will hold the "market portfolio," that is, a portfolio that is a microcosm of all capital assets, in which each type of capital asset has the same place proportionally in the rational investor's portfolio as it does in the capital market as a whole. . . If a public company were financed half by stock and half by bonds, a rational investor holding the market portfolio would have his investment in that corporation divided evenly between its stock and its bonds.

Id. at $217-18$.

66 Id. at 218. Greg Crespi attempts to build on Smith's analysis, arguing to broaden its reach by claiming that Smith's formulation of fiduciary duty does not depend on his strong investor diversification assumption. See Gregory Scott Crespi, Rethinking Corporate Fiduciary Duties: The Inefficiency of the Shareholder Primacy Norm, 55 SMU L. REV. 141 (2002). Crespi argues that in a world without transaction costs, even undiversified shareholders and bondholders would agree to FVM. See id. at 145 . He correctly notes at one 
Alon Chaver and Jesse Fried expand on Smith's analysis to argue for an even broader class of beneficiaries of directors' fiduciary duties. ${ }^{67}$ They question Smith's limitation that only financial claims deserve managerial fiduciary duties. Instead, Chaver and Fried point out an additional corporate constituency whose interests may conflict with financial claimants'. Parties owed contractual performance by the firm- "performance creditors"- need also to be part of the maximization calculus, lest managers take inefficient actions in insolvency to benefit financial claims at the expense of these performance creditors. Managers pursuing FVM might maximize financial claims but harm performance creditors by an even greater margin. Managers might underinvest in the firm's ability to perform its contracts, or they might precipitate inefficient contract breaches to maximize financial value. ${ }^{68}$ In other words, managers might make inefficient decisions. According to Chaver and Fried, an "FVM-plus-performance creditors" approach would solve this problem. Shareholders would benefit ex ante as well, since performance creditors would offer better terms up front given this endgame protection. ${ }^{69}$

\section{The Countertrend: Against Expanded Duty}

While recent corporate scholarship has trended toward expansion of fiduciary duties, ${ }^{70}$ a few scholars have pushed back against the trend in ways complementary to mine. ${ }^{71}$

point that this hypothetical bargain would include side payment arrangements to redistribute surplus from winners to losers in case either shareholders or bondholders suffered losses from a financial-value-maximizing investment. See id. Side payments transform FVM from a Kaldor-Hicks efficient rule into a Pareto efficient rule. See id. He fails to explain, however, how side payments could be implemented as part of a fiduciary duty rule, and it is unclear whether he would require them as part of his FVM approach.

67 See Chaver \& Fried, supra note 7.

68 Id. at 1831.

69 Id. at 1843.

70 See supra notes 3-6 and accompanying text.

71 Steve Bainbridge has taken issue with the Credit Lyonnais vicinity-of-insolvency duty to the "corporate enterprise," which he views to be an incoherent assignment. See Bainbridge, supra note 49, at 348. For Bainbridge, the real problem in distressed firms is managerial opportunism, not overinvestment. Because creditors are better able to protect themselves from that risk than shareholders, extending fiduciary duties to creditors is unjustified. See id. at 358-59. And finally, the business judgment rule offers sufficiently wide insulation that the number of cases implicated is likely to be small. See id. at 364. Earlier commentary on duty-shifting following on the heels of Credit Lyonnais includes Royce de R. Barondes, Fiduciary Duties of Officers and Directors of Distressed Corporations, 7 GEO. MASON L. REV. 45, 70-71 (1998) (arguing for more modest personal liability for directors); Lin, supra note 47, at 1501-07 (advocating that contracting costs be placed on creditors as optimal approach to maximization of firm value); and Steven L. Schwarcz, Rethinking a Corporation's Obligations to Creditors, 17 CARDOZO L. REV. 647, 651 (1996) (criticizing vagueness of vicinity-of-insolvency duties). See also Royce de R. Barondes et al., Twilight in the Zone of Insolvency: Fiduciary Duty and the Creditors of Troubled Companies, 1 J. Bus. \& TECH. L. 229 (2007). 
Henry $\mathrm{Hu}$ and Jay Westbrook argue that existing insolvency-based dutyshifting doctrine is unwarranted. ${ }^{72}$ They critique duty-shifting to creditors from a bankruptcy-based institutional analysis perspective. According to them, duty-shifting doctrine is a historical hangover, a crude attempt by nonbankruptcy courts to address corporate financial distress at a time when federal bankruptcy law did not exist. They note the absence in corporate law of any mechanism to resolve creditor conflicts and the difficulty for corporate managers in trying to chart a course that accounts for creditors' varying interests. $^{73} \mathrm{Hu}$ and Westbrook highlight the mismatch that occurs when fiduciary duties shift to creditors, and yet shareholders retain their voting rights, including the right to elect directors. ${ }^{74}$ Ultimately, they advocate abolition of the duty-shifting doctrine and further attention to the integration of corporate law with the corporate bankruptcy system. ${ }^{75}$

A related contribution comes from Douglas Baird and Todd Henderson. ${ }^{76}$ They acknowledge that financial innovation has rendered traditional shareholder primacy problematic. They doubt the efficacy of an expanded duty to maximize firm value, criticizing insolvency-based duty-shifting doctrine in the process. $^{77}$ They make the important observation that a transaction that is value-destroying ex post may have been part of an efficient

An even earlier generation of scholarship focused specifically on the shareholder-bondholder conflict in the wake of the leveraged buyout boom of the 1980s. See, e.g., William W. Bratton, Jr., Corporate Debt Relationships: Legal Theory in a Time of Restructuring, 1989 DuKE L.J. 92; Victor Brudney, Corporate Bondholders and Debtor Opportunism: In Bad Times and Good, 105 HARV. L. REV. 1821 (1992); Marcel Kahan \& Michael Klausner, Antitakeover Provisions in Bonds: Bondholder Protection or Management Entrenchment?, 40 UCLA L. REV. 931 (1993); Morey W. McDaniel, Bondholders and Corporate Governance, 41 Bus. LAw. 413 (1986); Morey W. McDaniel, Bondholders and Stockholders, 13 J. CoRP. L. 205 (1988); Lawrence E. Mitchell, The Fairness Rights of Corporate Bondholders, 65 N.Y.U. L. REV. 1165 (1990).

72 See Hu \& Westbrook, supra note 49.

73 Federal bankruptcy law is specifically designed to resolve conflicts among claimants—both conflicts over investment decisions and conflicts over distribution, two issues that corporate law is not designed to address and which do not arise outside of the financial distress context. See Hu \& Westbrook, supra note 49, at 1383 .

$74 \mathrm{Hu}$ and Westbrook go so far as to condemn duty shifting as a deprivation of shareholders' property rights. See id. at 1382.

75 See id. at $1369-78$

76 See Douglas G. Baird \& M. Todd Henderson, Other People's Money, 60 Stanford L. REV. (forthcoming 2008).

77 Id. at 19. 
ex ante bargain. ${ }^{78}$ A value-maximizing duty may get in the way of these ex ante efficient deals. ${ }^{79}$

These approaches dovetail nicely with mine. I criticize Creditor Duty from an incomplete contracts perspective, showing its incompatibility with the accepted incomplete contracts approach to corporate fiduciary duty.

\section{HYPOTHETICAL BARGAINS FOR CREDITORS}

This Part discusses the problems of attempting to construct hypothetical Creditor Duty bargains among creditors and shareholders.

According to the standard contractarian rationale for corporate fiduciary duties, transaction costs prevent managers and shareholders from writing a complete contract to govern their relationship. ${ }^{80}$ So hypothetical bargain analysis seeks to replicate the agreement the parties would have reached ex ante in the absence of transaction costs. ${ }^{81}$ The various Creditor Duty approaches-existing duty-shifting doctrine, as well as scholars' expansion proposals - are difficult to square with any cognizable hypothetical bargain that parties might reach.

Conceptually, Creditor Duty implicitly proceeds from two related premises. First, it assumes that all credit contracts are obligationally incomplete. ${ }^{82}$ The

78 The prospect of future value destruction may give managers the right incentive to avoid the circumstances leading to the value-reducing outcome. Id. at 30 .

79 Id. Baird and Henderson are far more skeptical than I regarding fiduciary duty for shareholders. They call for the abandonment of fiduciary duty altogether. They would rely entirely on private contracts to delineate the proper scope for managerial behavior. See id.

80 See EAsterbrooK \& Fischel, ECONOMic Structure of Corporate LAw, supra note 11, at 92 ("Socially optimal fiduciary rules approximate the bargain that investors and managers would have reached if they could have bargained (and enforced their agreements) at no cost."); Jonathan R. Macey, An Economic Analysis of the Various Rationales for Making Shareholders the Exclusive Beneficiaries of Corporate Fiduciary Duties, 21 SteTSOn L. REV. 23, 25 (1991) [hereinafter Macey, Economic Analysis].

81 This standard transaction cost rationale ordinarily calls for a majoritarian default-what most parties would contract for most of the time. See Ian Ayres \& Robert Gertner, Majoritarian vs. Minoritarian Defaults, 51 Stan. L. ReV. 1591, 1593 (1999). There may be other explanations as well. Considerations that might affect the appropriateness of majoritarian defaults include "(1) different private costs of contracting around, (2) different private costs of failing to contract around, (3) different public costs of filling gaps, and (4) ignorance of the law." Id. at 1593 .

82 Otherwise, there would be no need to resort to hypothetical contracts and gap fillers: "[B]efore implementing any default standard, courts need to establish, as a logically prior matter, rules for deciding when a contract is incomplete. Indeed, the litigants in many cases will argue not only about how the gap should be filled but also about whether there is a gap at all." Ian Ayres \& Robert Gertner, Filling Gaps in Incomplete Contracts: An Economic Theory of Default Rules, 99 YALE L.J. 87, 119 (1989) (footnotes omitted); see also 
default protection of Creditor Duty applies indiscriminately to all creditors. Such a broad and general mandatory default rule necessarily implies that all credit contracts have gaps. Second, Creditor Duty assumes that the appropriate gap filling provision-across all credit contracts-should be expanded fiduciary duties to include creditors. In a world without transaction costs, so the analysis goes, shareholders and creditors would all agree to this. Both assumptions are problematic. Two underappreciated features of corporate creditors help explain why. First, creditors are heterogeneous and their interests may conflict. Second-and related to the first-creditors are interdependent.

A crucial difference between shareholders and creditors is that creditor interests are not unitary and may often conflict. By the time the firm is in distress, creditors are competitors, not allies. They understand that when the firm goes into distress, they will be fighting one another over an undersized and shrinking pie. While shareholders ordinarily share pro rata, one creditor's gain is typically another's loss when the firm is at or near insolvency. ${ }^{83}$ By contrast, Creditor Duty relies on a highly stylized model of the debt-equity conflict, treating all debt as undifferentiated and unitary unsecured debt. Conflict among creditors is ignored. Creditor Duty reduces a complex multiparty conflict into a seeming bilateral bargain. Hypothetical consensus appears easily proclaimed.

This multiparty consensus among conflicting creditors-our second assumption above-seems dubious, however. Creditor Duty imagines that each creditor would agree to empower every other creditor to challenge the firm's course of action as a breach of duty. But creditors have varying risk preferences and varying contract protections. Those with superior contract protection will prefer their actual contract rights to any generalized judiciallyimposed hypothetical creditor-shareholder bargain that serves only to empower creditors with inferior contract rights. Not all creditors would agree to this.

In addition to the substantive problems with any hypothetical Creditor Duty bargain, it is far from clear that all credit contracts have gaps that need filling.

$i d$. (noting that varying levels of effort required to contract around default rules also determine when a "gap" exists for courts to fill).

83 While creditors of equal priority ordinarily share pro rata in bankruptcy, outside of formal bankruptcy proceedings, no general sharing rule applies. ELIZABETH WARREN \& JAY LAWRENCE Westbrook, THE LAW OF DEBTORS AND CREDITORS 48 (5th ed. 2006). Instead, creditors race against one another to enforce collection rights against the debtor's free assets. Id. First-come, first-served is the general rule outside of bankruptcy. Id. 
Credit contracts vary, no doubt. Some contain elaborate covenant protections; others are sparse. This variation does not necessarily suggest, however, that some or all credit contracts are incomplete. Creditor interdependence and the theory of delegated monitoring explain this variation among credit contracts. ${ }^{84}$ A borrower and its creditors understandably seek to minimize total monitoring costs. The bank lender is typically the low-cost monitor. Other creditors and the borrower may therefore be happy to delegate monitoring responsibilities to the bank. Other creditors free-ride on the bank's efforts and each creditor prices accordingly. Under this theory, sparse credit contracts are not an artifact of transaction costs. Variation among credit contracts would exist even in a world without transaction costs. Delegated monitoring explains why even credit contracts with minimal creditor protections are not necessarily incomplete. If not all credit contracts are incomplete, then a general Creditor Duty default rule-applicable to all credit contracts—is inapt.

The problems with Creditor Duty are not limited to the theoretical. Creditor Duty is also costly. It may lead to undesirable litigation and underinvestment. In addition, because the duty runs generally to all creditors, it is a default rule that is not easily altered by express contract.

In Part II.A and Part II.B, I explain creditor heterogeneity and creditor interdependence. These features underlie the theory of delegated monitoring, which I also explain in Part II.B. In Part II.C, I tie together these various parts of the incomplete contracts analysis, concluding that Creditor Duty cannot be rationalized as a hypothetical bargain. In Part II.D, I point out specific problems of financial-value-maximization proposals. In Part II.E, I discuss the costs of Creditor Duty. It is not free. I summarize in Part II.F.

\section{A. Creditor Heterogeneity}

Creditors are a much more diverse bunch of rights-holders than are shareholders. Common shares are cookie-cutter packages of rights: the nominal rights of each share are identical with those of every other share. Their commonality facilitates their public trading. Only because share rights within a class are identical can the shares trade freely in large quantities in

84 See infra Part II.B. 
impersonal markets. ${ }^{85}$ Moreover, modern finance theory supports a managerial presumption of unitary shareholder interests. ${ }^{86}$

Debt as a class, by contrast, is a mixed bag. Debt contracts-especially of public companies-comprise a fairly heterogeneous bunch. Debt includes bank debt (sometimes secured), bond debt, trade debt, federal, state, and local tax liabilities, pension funding obligations, tort liabilities, and others. ${ }^{87}$ Debt varies, most obviously, in its liquidity and priority. While bond debt trades in impersonal markets, and trading in bank debt is increasingly common, other forms of debt are less frequently traded. ${ }^{88}$ Credit derivatives-typically traded by institutions-further facilitate certain creditors' adjustment of their exposure to borrower firm risk, ${ }^{89}$ as well as affecting their incentives to monitor and pursue collection from borrower firms. ${ }^{90}$ Debt contracts will also vary in their protective provisions. Some will be more protective than othersexplicitly constraining borrower opportunism with covenants and non-payment default triggers. Some contracts will enjoy greater potential for renegotiation.

Courts and scholars have largely ignored these differences among creditors in formulating Creditor Duty approaches. Duty-shifting cases enunciating the traditional doctrine, for example, treat creditors as one undifferentiated class.

85 Of course, public companies may issue various classes of securities with differing terms, including differing classes of equity securities. However, rights are uniform within each class.

86 See Hu \& Westbrook, supra note 49, at 1362; Henry T.C. Hu, Risk, Time, and Fiduciary Principles in Corporate Investment, 38 UCLA L. REV. 277, 287 (1990) (explaining that optimal capital budgeting technique to maximize share price will benefit all shareholders, independent of individual risk and time preferences).

87 Tort liabilities and tax liabilities, of course, are not based in contract—at least not in any conventional sense-and I do not discuss them further in this Article. Given the involuntary nature of tort claims, scholars generally agree that, upon the firm's demise, these claims should be accorded special treatment-either modification of corporate limited liability rules to allow personal recourse to shareholders, see Henry Hansmann \& Reinier Kraakman, Toward Unlimited Shareholder Liability for Corporate Torts, 100 YALE L.J. 1879, 1907 (1991) (advocating pro rata shareholder liability for tort obligations), the granting of priority over secured and other contract creditors to tort claimants, see Lynn M. LoPucki, The Unsecured Creditor's Bargain, 80 VA. L. REV. 1887, 1908-09 (1994), or both. See also David W. Leebron, Limited Liability, Tort Victims, and Creditors, 91 CoLuM. L. REv. 1565, 1569 (1991) (arguing that investors should be subject to pro rata unlimited liability and that tort claimants should be given priority in bankruptcy proceedings); Jonathan C. Lipson, Directors' Duties to Creditors: Power Imbalance and the Financially Distressed Corporation, 50 UCLA L. REV. 1189, 1189 (2003) (distinguishing between creditors with high and low levels of "volition, cognition, and exit").

88 Trade debt is often sold to factors, for which institutional capacity and scale economies facilitate collection.

89 See generally Frank Partnoy \& David A. Skeel, Jr., The Promise and Perils of Credit Derivatives, 75 U. CIN. L. REV. 1019 (2007).

90 Stephen J. Lubben, Credit Derivatives \& the Future of Chapter 11, at 16 (July 17, 2007) (unpublished manuscript, on file with author), available at $\mathrm{http}: / / \mathrm{ssrn}$. com/abstract=906613. 
Typically facing only one creditor in any duty-shifting case, courts nowhere suggest that creditors as a group may have divergent interests or risk preferences. Instead, courts merely declare the duty shift to creditors generally. ${ }^{91}$ Scholars' proposals take the same approach. Thomas Smith's FVM proposal, for example, highlights the conflict between shareholders and creditors, but he makes no mention that creditors' interests may conflict. ${ }^{92}$

The various differences in credit terms and conditions affect not only creditors' relations with their borrowers but also creditors' relations inter se. Once the firm is in distress, each creditor finds itself competing with other creditors for payment. Its once-bilateral relation with the borrower turns into a multilateral contest with other creditors. These various differentiations suggest that creditors may have little common ground in terms of their preferences over a one-size-fits-all default rule. Below, I elaborate on some important differences among creditors.

\section{Security Interests and Residual Claimant Status}

Whether a creditor enjoys a security interest has a crucial effect on its risk preferences. At the limit, an oversecured creditor may be indifferent as to the firm's performance. Assuming the value of its collateral is stable, that creditor will be paid in full whether the firm recovers from its reverses or not. ${ }^{93}$ If the collateral value is unstable, that creditor may prefer early liquidation of the firm's assets, to the detriment of not only equity holders but also unsecured creditors. Depending on the context, the secured creditor may be more or less willing than unsecured creditors to endorse managers' preference for risky investments when the firm is marginally solvent. ${ }^{94}$

More generally, unsecured creditors' fates are much more closely tied to the fortunes of the firm than is the case with secured creditors. The former therefore have a much stronger claim to residual status. To the extent that one accepts the traditional notion that fiduciary duties should run to the firm's residual claimants—and should "shift" when the identity of the firm's residual

\footnotetext{
91 See, e.g., Prod. Res. Group, L.L.C. v. NCT Group, Inc., 863 A.2d 772, 790-91 (Del. Ch. 2004) ("When a firm has reached the point of insolvency, it is settled that under Delaware law, the firm's directors are said to owe fiduciary duties to the company's creditors.").

92 See Smith, supra note 7, at 217-19.

93 In theory, the result in bankruptcy should be the same. See 11 U.S.C. §362(d) (2006) (requiring adequate protection of interest in property in order to defeat relief from stay motion).

94 This divergence over investment policy will exist between any two classes of financial claims with differing payment priorities in liquidation.
} 
claimants changes-unsecured creditors seem far more deserving than secured creditors.

To date, even this simple distinction has eluded courts and commentators. None have suggested that Creditor Duty should distinguish secured from unsecured creditors. ${ }^{95}$ Outside of the Creditor Duty context, however, the conflicts between secured and unsecured creditors of an insolvent firm are well understood. ${ }^{96}$ Secured and unsecured creditors will likely have irreconcilable differences over investment policy, similar to the classic conflict between unsecured creditors and equity holders. Moreover, secured creditors' rights to collateral generally give them better leverage over firm management than unsecured creditors enjoy.

\section{Nonfinancial Interests}

Even among unsecured creditors, variation exists. Financial creditors are different from trade creditors. A trade creditor-a supplier of goods or services to the firm-makes its money primarily from the sale of its goods or services. Extensions of credit merely facilitate the trade creditor's primary business of selling its product. Its profits typically come predominantly from sales, not financing. ${ }^{97}$ By contrast, the financial creditor's profit comes almost exclusively from interest and fees charged to its borrowers.

Because their businesses differ, financial creditors and trade creditors will often differ in their preferences over the borrower firm's fate. Liquidation may maximize a financial creditor's recovery, but it eliminates a customer for the trade creditor, who often has a greater stake in the firm's survival than does the financial creditor. Similarly, employee pension funds—often major creditors

95 Lest one think this point so obvious as to be implicitly understood, note that the seminal Credit Lyonnais decision involved a secured creditor whose security including a pledge of stock sufficient to control the borrower firm, and by the time of the litigation, the creditor had exercised its right to vote its stock and elect its own board. See Credit Lyonnais Bank Nederland, N.V. v. Pathe Commc'ns Corp., No. 12,1240, 17 DEL. J. CORP. L. 1099, 1106-09 WL 277613 (Del. Ch. 1991); see infra Part III.C.1.

96 See, e.g., Lucian Arye Bebchuk \& Jesse M. Fried, The Uneasy Case for the Priority of Secured Claims in Bankruptcy, 105 YALE L.J. 857 (1996) (arguing that the institution of secured credit may be inefficient); Lucian Arye Bebchuk \& Jesse M. Fried, The Uneasy Case for the Priority of Secured Claims in Bankruptcy: Further Thoughts and a Reply to Critics, 82 CORNELL L. REV. 1279 (1997) (debating efficiency of secured debt).

97 This may not always be true, of course. For example, General Motors Acceptance Corporation, the finance and insurance arm of General Motors, generates income that often rivals that of the GM's vehicle sales operations. See 2006 Form 10-K for General Motors Corp. (Mar. 28, 2006) (noting GMAC's \$2.4 billion net income for 2005 and net losses for GM's automotive operations). The critical point, however, is that for a given firm, some creditors are likely to have nonfinancial interests at stake. 
of distressed public companies-will care about a firm's survival as an employer, so that the decision whether to push for liquidation will involve more than the short-term financial calculation another creditor might make.

\section{Contract Protections and Renegotiation Prospects}

Related to the distinction between financial creditors and trade creditors, certain creditors typically enjoy better-defined contract protections than others. Contracts will vary in their initial covenants and default triggers, ${ }^{98}$ which are largely targeted at constraining borrower risk-taking. ${ }^{99}$ Financial creditors generally enjoy more elaborate contract protections than trade creditors-not surprising given the relative importance of financing revenues to the financial creditor's business. Trade credit is often arranged quite informally, with any agreement running only a few pages in length. Bank and bond debt, by contrast, is elaborately contracted, with documents running into the hundreds and perhaps thousands of pages.

These contracting differences are understandable given the differing magnitudes of exposure and differing noncontractual enforcement devices available. Trade credit, for example, is typically granted in small increments, with future shipments dependent on repayment of outstanding credit. The trade creditor's exposure is therefore limited, and its implicit threat to withhold future shipments may often serve as a powerful nonlegal inducement to the borrower's repayment. ${ }^{100}$ Moreover, because the trade creditor's primary objective is to sell its wares to the borrower, it may be more focused on maintaining the quality and competitiveness of its products than on the detailed terms of its financing arrangements. On the other hand, banks are in the business of lending money, and the money they lend may be advanced in large

98 See Mitu Gulati \& George Triantis, Contracts Without Law: Sovereign Versus Corporate Debt, 75 U. CIN. L. REv. 977, 979-80 (2007) (discussing types of loan covenants).

99 See Smith \& Warner, supra note 48, at 118-19.

100 The recent practice in Chapter 11 bankruptcy cases of paying "critical vendors" attests to the leverage that suppliers may have on a firm. The package of first-day orders the judge signs more and more commonly includes an order approving payments to critical vendors. These orders authorize the debtor to make postpetition payments to certain vendors on account of their prepetition debts, based on vendors' threats to discontinue supplying inputs to the debtor absent debt repayment. Upon the debtor's representation that its business will be severely compromised if the vendor stops shipping, the judge typically signs the order. The problem, however, is that this practice has no legal basis in the Bankruptcy Code. The legality of criticalvendor orders has been challenged. See In re Kmart Corp., 359 F.3d 866 (7th Cir. 2004) (affirming reversal of bankruptcy court's critical-vendor order). Bankruptcy court authorization of these payments, despite their questionable legality, gives some sense for the extralegal inducements suppliers may have at their disposal to coerce repayment from their borrowers even outside the bankruptcy context. 
tranches. The bank's exposure might be quite large relative to the borrower firm's cash flows and assets. Understandably, then, bank debt contracts are typically quite elaborate in terms of covenants and defaults. ${ }^{101}$

Similarly, creditors' varying institutional constraints will affect their capacity to renegotiate their credit contracts, which also affects initial contract terms. These differences exist even among financial creditors. For example, banks generally enjoy tighter covenants than public bondholders. ${ }^{102}$ Moreover, the initial bank credit agreement is structured specifically with renegotiation in mind. ${ }^{103}$ This difference in initial terms is due largely to the fact that banks can more readily monitor their borrowers and renegotiate if necessary. While large loans are typically syndicated-a group of banks shares the loan exposure in specified percentages-collective action problems are avoided through intercreditor agreements among syndicate banks. ${ }^{104}$ A lead bank is typically empowered to make many enforcement decisions on behalf of the

101 For instance, use of loan proceeds is typically restricted. Regular operating reports to the bank are required. Negative covenants may restrict the firm's ability to engage in many types of transactions without the bank's consent. The firm's latitude to incur new debt, make investments or distributions, engage in transactions with affiliates, sell substantial assets, give liens on its assets, merge, or change the nature of its business, are all often restricted in the loan agreement. Myriad technical default provisions in the contract enable the bank to tighten the reins if the firm falters. Such technical default triggers include financial covenants, which may, for example, require the firm to maintain certain levels of net worth, tangible assets, total capital relative to debt, and cash flow relative to debt service obligations.

Bond indentures contain similar provisions. See, e.g., U.S. Bank Nat'l Ass'n v. U.S. Timberlands Klamath Falls, L.L.C., 864 A.2d 930 (Del. Ch. 2004). The court's detailed technical discussion of note indenture provisions in that case illustrates the thoroughness and complexity of creditor protections in standard credit arrangements. Id. at 939-51.

102 See Marcel Kahan \& Bruce Tuckman, Do Bondholders Lose from Junk Bond Covenant Changes?, 66 J. Bus. 499, 501 (1993); Amy P. Sweeney, Debt-Covenant Violations and Managers' Accounting Responses, 17 J. ACCT. \& ECON. 281, 290 (1994); Sudheer Chava \& Michael R. Roberts, How Does Financing Impact Investment? The Role of Debt Covenants (Aug. 2, 2007) (unpublished manuscript, on file with author), available at http://ssrn.com/abstract=854324; Greg Nini et al., Creditor Control Rights and Firm Investment Policy (Feb. 2007) (unpublished manuscript, on file with author), available at http://ssrn.com/abstract= 928688.

103 See Charles Kahn \& Gur Huberman, Defaul, Foreclosure, and Strategic Renegotiation, LAW \& CONTEMP. Probs., Winter 1989, at 49, 51 (explaining that credit agreement puts enormous negotiating leverage in creditor's hands, not necessarily to enable creditor to foreclose but to extract value from borrower under conditions of information asymmetry); see also Michael R. Roberts \& Amir Sufi, Contingency and Renegotiation of Financial Contracts: Evidence from Private Credit Agreements (Sep. 27, 2007) (unpublished manuscript, on file with author), available at http://ssrn.com/abstract=1017629 (finding over a ten-year sample period that over $90 \%$ of long-term private debt contracts of public companies are renegotiated prior to stated maturity).

104 See Lee C. Buchheit \& Jeremiah S. Pam, The Pari Passu Clause in Sovereign Debt Instruments, 53 EMORY L.J. 869, 918 (2004) (noting that intercreditor agreements allow syndicate banks to share disproportionate payments or recoveries ratably). 
syndicate. ${ }^{105}$ Banks therefore have some capacity to anticipate problems with their borrower and work with the borrower to resolve problems. Bondholders, by contrast, enjoy no similar arrangements, and collective action is more costly. Bondholders are likely to be relatively widely dispersed, and unlike syndicated bank loans, the agent for bondholders-the indenture trustee-has relatively weak powers to act on behalf of the bondholders. ${ }^{106}$ Modification of bond terms typically requires a consent solicitation. ${ }^{107}$ Modification of principal or interest provisions requires the approval of each affected bondholder. ${ }^{108}$ Changing other terms typically requires approval by a majority or two-thirds of the face amount of the bonds. ${ }^{109}$ Because of the hurdles to collective action, bond covenants must be looser than bank debt covenants. Bond indentures contain no simple device to work out problems with the borrower.

While renegotiation possibilities affect initial contract terms, actual renegotiation of course enables the parties to adjust their contracts for new circumstances. Because renegotiation may be more readily available for some credit contracts than others, credit contracts will vary in the protections and remedies the creditor enjoys by the time the firm is in distress. Bank debt, for example, will typically be renegotiated when a firm is in distress. ${ }^{110}$ Once the debtor defaults, the bank enjoys enormous leverage to negotiate additional protections it desires. ${ }^{111}$ A properly drafted credit agreement ordinarily offers default triggers and remedies that would allow the creditor to destroy the business. ${ }^{112}$ In exchange for forbearance, the lender generally gets what it

105 See J. Thomas Cookson, Loan Participation Agreements as Securities: Judicial Interpretations of The Securities Act of 1933 and The Securities Exchange Act of 1934, 24 WM. \& MARY L. REV. 295, 296-98 (1983) (discussing the lead bank's primary role in negotiating with the borrower and concluding the loan agreement).

106 See Mark J. Roe, The Voting Prohibition in Bond Workouts, 97 YALE L.J. 232, 251 (1987) (noting that the Trust Indenture Act of 1939 limited the modifiability of bond terms for fear of insider control).

107 The consent solicitation is often accompanied by an exchange offer or tender offer. See Kahan \& Tuckman, supra note 102, at 500.

108 See Roe, supra note 106, at 251. The same is generally true for a syndicated bank loan, but again, collective action among banks is much easier to accomplish.

109 Kahan \& Tuckman, supra note 102, at 501-02.

110 See Gur Huberman \& Charles Kahn, Limited Contract Enforcement and Strategic Renegotiation, 78 AM. ECON. ReV. 471, 471 (1988); Kahn \& Huberman, supra note 103, at 51; Roberts \& Sufi, supra note 103.

111 See Lawrence Ponoroff, Why Don't You Stay?: The Current State of the Law Concerning the Enforceability of Prefiling Stay Waivers, 7 J. BANKR. L. \& PRAC. 505, 508 (1998) (noting lenders' post-default leverage).

112 The lender's simplest leverage on default is its discretion to seize the borrower's cash and cut off its credit. A bank lender often requires its borrowers to maintain their deposit accounts with the bank. This creates a setoff right for the bank should the borrower default. The bank may seize the amounts in the deposit accounts to offset against the outstanding loan. This remedy brings the business to a halt. Formal acceleration 
wants in workout. Serial renegotiation of a loan is not unusual. Bank and borrower may make fine adjustments to reflect the changing circumstances of the borrower's business. ${ }^{113}$ The bank's protections may therefore be very finely tuned by the time the borrower is in distress.

\section{B. Creditor Interdependence: The Theory of Delegated Monitoring}

While creditors of a given firm vary in their exposure, their contract protections, and institutional capacities, their interests in monitoring the borrower overlap to a fair degree. Opportunistic borrower behavior is likely to be harmful to all creditors. ${ }^{114}$ Excessive risk taking, for example, or excessive dividends to shareholders are forms of opportunism that all creditors are likely to oppose. Because of these overlapping interests, one creditor's monitoring benefits all creditors. Conversely, multiple monitors may be redundant and costly.

\section{Banks as Delegated Monitors}

A well-developed finance literature explains banks' special monitoring abilities. $^{115}$ Banks' institutional advantages allow them to monitor at lower

of the debt is another severe option. See R. Wilson Freyermuth, Enforcement of Acceleration Provisions and the Rhetoric of Good Faith, 1998 BYU L. REV. 1035, 1035-46 (discussing acceleration of debt contracts). Formal acceleration would typically trigger cross-default provisions in the firm's other debt contracts and other agreements. Id. at 1042 n.14. Other creditors would therefore also be entitled to pursue collection against the firm. Triggering a race among creditors to seize the firm's assets would damage the business severely and might cause the firm's demise. If the lender were secured under the original loan, seizing its collateral would similarly hobble if not destroy the business.

113 See Tung, supra note 55, at 620.

114 This is not to ignore intercreditor conflicts. As among creditors, the likely problem would be that the senior bank creditor sets the investment restrictions too tightly—not too loosely—since its recovery is capped, such that junior creditors might see no recovery. However, this may not be a serious problem, as investment restrictions cannot generally be set so precisely as to cut out specific layers of claims, and in any event, the bank will not want to choke of investment entirely, only the Hail Mary risks.

115 See, e.g., Tim S. Campbell \& William A. Kracaw, Information Production, Market Signaling, and the Theory of Financial Intermediation, 35 J. FIN. 863, 880 (1980) (arguing that banks gain an advantage through their ability to coordinate production of information and services); Douglas W. Diamond, Financial Intermediation and Delegated Monitoring, 51 REv. ECON. STUD. 393, 409-10 (1984) (discussing the advantages of using banks as financial intermediaries); Eugene F. Fama, What's Different About Banks?, 15 J. MONETARY ECON. 29, 35-39 (1985) (discussing the comparative advantages of banks as lenders); Christopher James, Some Evidence on the Uniqueness of Bank Loans, 19 J. FIN. ECON. 217 passim (1987) (arguing that banks are able to provide special lending services that other lenders cannot); Ram T.S. Ramakrishnan \& Anjan V. Thakor, Information Reliability and a Theory of Financial Intermediation, 51 REV. ECON. STUD. 415, 416 (1984) (discussing the advantages of building coalitions among financial intermediaries with respect to production of information). 
cost than other creditors. ${ }^{116}$ Banks therefore typically play the role of delegated monitor. ${ }^{117}$ Note that the borrower and its creditors have a collective interest in the efficient delegation of monitoring responsibilities. It should not be surprising that bank covenants are more stringent than covenants in publicly issued bonds, or that trade creditors may enjoy fewer contractual protections than banks. ${ }^{118}$ The borrower is vitally interested in coordinating these various credit arrangements to minimize total monitoring costs, which leads to lower borrowing costs. ${ }^{19}$ The borrower is therefore willing to grant covenant protections to the bank-the low-cost monitor-that it may not accord other creditors. These other creditors price their credit accordingly. They may not enjoy many covenant protections or non-payment default triggers-which they are not institutionally equipped to monitor in any event—but they know the bank has extended credit and is monitoring, and they themselves avoid incurring monitoring costs. ${ }^{120}$ Other creditors free-ride on the bank's efforts. ${ }^{121}$ Conversely, the bank knows that other creditors have sparse or no contract protections and so will not monitor. ${ }^{122}$ The bank therefore does not have the option to free-ride; it must monitor. ${ }^{123}$

In fact, bank loan terms often mimic the duty-shifting protection that some courts have imposed for the benefit of creditors generally. Similar to the insolvency trigger for duty-shifting, capital structure infirmity typically triggers default under a bank loan agreement. Such agreements often contain tailored capital structure requirements-minimum tangible net worth or a minimum debt-to-equity ratio, for example. And to the extent the point of Creditor Duty generally is to curb overinvestment, loan agreementsespecially those renegotiated upon default-typically contain constraints on managers' investment decisions and uses of cash. Covenants restricting capital expenditures are common, especially following the borrower's poor

116 For example, besides elaborate covenant protections, banks enjoy regular reporting from the borrower and can easily monitor borrower cash flows. See supra notes 101, 112 and accompanying text.

117 Diamond, supra note 115 , at 393.

118 See Mark E. Van Der Weide, Against Fiduciary Duties to Corporate Stakeholders, 21 DEL. J. CoRP. L. 27, 49-50 (1996) ("Ordinary trade creditors . . . often do not have the bargaining power to extract contractual concessions from a firm.").

119 See George G. Triantis \& Ronald J. Daniels, The Role of Debt in Interactive Corporate Governance, 83 CAL. L. REV. 1073, 1090 (1995).

120 Id. This cross-monitoring explanation for the structuring of corporate debt has significant empirical support in the finance literature. See infra notes 129-32 and accompanying text.

121 See Saul Levmore, Monitors and Freeriders in Commercial and Corporate Settings, 92 YALE L.J. 49, 53-54 (1982) (discussing the free-riding creditor phenomenon).

122 Gulati \& Triantis, supra note 98 , at 982.

123 Id. 
performance or default. ${ }^{124}$ Similarly, covenants often require the defaulted borrower to turn over its excess cash to the bank in order to pay down the outstanding debt. At the limit, the bank may impose a lock box arrangement upon default, through which the bank literally controls all of the firm's cash both coming in and going out. ${ }^{125}$

A recent empirical study suggests that banks may be quite effective at controlling overinvestment on their own. Nini, Smith, and Sufi have studied bank loan covenants restricting capital expenditures and found that such covenants may be efficient. ${ }^{126}$ Imposition of capital expenditure restrictions turns out to be extremely sensitive to firm performance. A borrower that has violated a covenant, has lower cash flow, or has lower credit quality is more likely to be subject to such a restriction, and the elasticity of the restriction with respect to a covenant violation is significantly larger than the elasticity of other important loan terms, such as the interest rate spread, collateralization of the loan, or dividend restrictions. ${ }^{127}$ In other words, banks make relatively fine adjustments in their contractual investment restrictions in response to firms' financial condition. Given that up to $80 \%$ of public companies have private credit agreements, ${ }^{128}$ these empirical findings suggest that banks may have wide influence in curbing managers' overinvestment tendencies, to the benefit of all claimants.

More generally, an extensive corporate finance literature documents the benefits of cross-monitoring among creditors. As for bank monitoring specifically, one empirical study suggests that bank monitoring benefits bondholders. ${ }^{129}$ It shows that the presence of bank debt reduces the borrower's costs of issuing bonds. ${ }^{130}$ At-issue yield spreads for firms' first public debt offerings were found to be lower for issuers with pre-existing bank loans, ${ }^{131}$

124 See Nini et al., supra note 102.

125 See Laura Lin, The Information Content of a Bank's Involvement in Private Workouts, 3 GEO. MASON INDEP. L. REV. 97, 110 \& n.35 (1994).

126 See Nini et al., supra note 102. They find that firms with such restriction show large and statistically significant increases in firm value (as measured by market-to-book value) and operating performance (as measured by return on assets) in the year after imposition of the restriction. Id. at 4 .

127 Id. at $20-21$.

$128 I d$. at 2.

129 See Sudip Datta et al., Bank Monitoring and the Pricing of Corporate Public Debt, 51 J. Fin. ECON. 435, 448-49 (1999).

130 See id. at 448.

131 For the sample period, the presence of a pre-existing bank loan reduced at-issue yield spreads for borrower firms' first public debt offerings by an average of sixty-eight basis points, which was both statistically and economically significant. $I d$. 
suggesting that bondholder risk is lower when a bank is already monitoring the firm. Bank monitoring may reduce moral hazard in a way that bondholders by themselves cannot. ${ }^{132}$

\section{Intercreditor Conflict}

Creditors' interests begin to diverge as a borrower approaches financial distress. ${ }^{133}$ When the borrower cannot repay all its debts, creditors become competitors, not allies. Passive free riding on the bank's monitoring becomes unattractive for other creditors. Even in this situation, though, creditors remain interdependent. With its superior information, the bank is likely to take the lead in managing the borrower's distress. It may renegotiate its loanmodifying the maturity, taking security, perhaps even extending additional credit, depending on the borrower's prospects. Or instead it may exit, declaring a default and pursuing collection against the borrower's assets. In either case, the bank's action provides a signal to other creditors that enables them to act in their own interests. ${ }^{134}$ A successful renegotiation and rehabilitation of the borrower of course benefits other creditors as well. Even exit by the bank may aid other creditors. ${ }^{135}$

No doubt, the bank may be tempted to advantage itself at other creditors' expense. It may attempt to extract opportunistic payments from the borrower. It may mask its collection actions or manage their timing to reduce the usefulness of any signal conveyed to other creditors. Legal rules exist, however, to constrain the bank's ability to do these things. Rules encourage early action by banks and other informed creditors. Early signaling by an informed creditor makes it easier for other creditors to act as well. ${ }^{136}$ Preference rules in bankruptcy, for example, force an unsecured creditor to disgorge any non-ordinary course payments or security interests it receives

132 Id. Another study shows, conversely, that the presence of publicly rated debt reduces bank loan spreads, suggesting that monitoring by public debt holders reduces the risks of bank lending. See James R. Booth, Contract Costs, Bank Loans, and the Cross-Monitoring Hypothesis, 31 J. FIN. ECON. 25 (1992).

133 See Triantis \& Daniels, supra note 119, at 1090-91 (noting that a borrower's financial instability may cause creditors' interests to diverge).

134 For a public company, default on a bank loan is likely to be a fairly public event. Its demise will likely be chronicled in the financial press. If nothing else, the company is required to file a Form 8-K disclosure with the Securities and Exchange Commission within four business days of its default on a material loan. See United States Securities and Exchange Commission Form 8-K, at 9-10 (Item 2.04), available at http://sec.gov/ about/forms/form8-k.pdf.

135 See Triantis \& Daniels, supra note 119, at 1095-96 (noting that a bank's exit may act as a beneficial signal to other governance players).

136 Triantis \& Daniels, supra note 119, at 1095-96. 
from an insolvent debtor within the ninety-day period preceding bankruptcy. ${ }^{137}$ Earlier transfers-transfers made before this ninety-day pre-bankruptcy period-the bank gets to keep, thereby encouraging the bank to take action sooner rather than later. A secured creditor also has incentive to act early. If it fails to seize and sell its collateral before the borrower files for bankruptcy, the automatic stay in bankruptcy prevents it from doing so, ${ }^{138}$ and it must return the collateral to the debtor's possession. ${ }^{139}$ Banks or other informed creditors therefore have some incentive to act before the borrower's distress becomes severe.

Preference rules and other doctrines also constrain the bank from directly advantaging itself at the expense of other creditors. Preference rules only apply when the bank attempts to improve its position against the insolvent borrower. ${ }^{140}$ Payments or security interests from a solvent borrower, however, do not impede other creditors' collection efforts. These are also safe from preference avoidance. The doctrine of equitable subordination also constrains the bank from egregious collection actions. The doctrine subjects a lender's claim to subordination if the lender has engaged in inequitable conduct resulting in injury to other creditors or an unfair advantage to the lender. ${ }^{141}$ For example, a lender that uses its leverage over the borrower to control the borrower's management to its own advantage and the detriment of other creditors runs a high risk of subordination. ${ }^{142}$

Even as the borrower approaches distress, then, creditors with conflicting interests benefit from delegated monitoring. The theory captures the idea of creditor interdependence. It explains why credit contracts vary and why this makes sense.

\section{The Creditors' Hypothetical Bargain?}

The theory of delegated monitoring sheds important light on the two important questions implicated by Creditor Duty. First, are all credit contracts incomplete? Do gaps exist that need filling by Creditor Duty? Second,

13711 U.S.C. $\$ 547$ (2006). While the debtor is required to be insolvent at the time of the payment, an objecting creditor enjoys a presumption of the debtor's insolvency during the ninety-day period. Id. $§ 547(\mathrm{f})$.

138 Id. $\$ 362$.

139 Id. $\$ 542(\mathrm{a})$.

$140 I d . \$ 547(\mathrm{~b})(3)$.

141 Id. $\S 510(\mathrm{c}) ; 4$ COLLIER ON BANKRUPTCY $\S 510.5$ (15th rev. ed.).

142 See In re Fabricators, Inc., 926 F.2d 1458 (5th Cir. 1991). 
assuming all credit contracts are incomplete, can a hypothetical bargain analysis possibly yield Creditor Duty?

Creditor Duty simplifies (artificially) the project of constructing a hypothetical bargain by treating all debt as unitary unsecured debt. What in reality would require a complicated interdependent multiparty bargain framework, Creditor Duty has reduced to a bilateral bargain. On that basis, assuming gaps and declaring hypothetical consensus are relatively easy, deceptively easy. But creditors are not unitary. Their interests may conflict or coincide, depending on the circumstances. The theory of delegated monitoring highlights the collective and interdependent nature of creditors' relations inter se. This perspective helps explain why not all—and perhaps not any-credit contracts have gaps for Creditor Duty to fill. And even assuming all credit contracts had gaps, Creditor Duty cannot be derived from any plausible hypothetical bargain analysis.

\section{Not All Credit Contracts Have Gaps}

Delegated monitoring explains why some creditors do not enjoy elaborate covenant protections in their contracts. Admittedly, viewing any individual credit contract ex post—as courts must do-may fail to illuminate interdependence among creditors. A single credit contract in isolation might look woefully incomplete, begging for judicial intervention. But the theory of delegated monitoring makes clear that creditors' varying rights against a common borrower are not an oversight or a result of daunting transaction costs. Even in a world without transaction costs, credit contracts would vary as described. Some would have minimal contract protections for the creditor. It seems difficult to assume, then, as Creditor Duty inevitably must, that all credit contracts have a gap that needs filling. In the incomplete contracts vernacular, these contracts may be obligationally complete-they fully specify the borrower's repayment obligation in all future states of the world. ${ }^{143}$ Moreover,

143 See Ian Ayres \& Robert Gertner, Strategic Contractual Inefficiency and the Optimal Choice of Legal Rules, 101 YALE L.J. 729, 731 (1992). Contracts do not generally include a provision setting the damages for breach, and in that sense, they may be obligationally incomplete. Id. But with credit contracts, damage calculations are likely to be fairly straightforward under the contract terms, as compared to other types of contracts. Besides outstanding principal and interest, the contract may require a penalty rate of interest, as well as payment of the creditor's collection costs. Though these latter costs cannot be known ahead of time, the range of disagreement as to the total amount owed is likely to be small. In any event, incompleteness in the specification of a damages remedy does not invite Creditor Duty gap filling, which goes to an entirely separate issue. 
it seems difficult to assume that any credit contract is obligationally incomplete merely because it lacks covenants or other contract protections besides the ultimate repayment obligation.

Existing contracts also flatly contradict the assumption that all credit contracts must be incomplete, at least in any way that would require Creditor Duty as an appropriate gap-filling rule. Renegotiation of bank credit agreements happens regularly. One recent study found that over a ten-year period, $90 \%$ of long-term private debt contracts of public companies are renegotiated prior to stated maturity. ${ }^{144}$ And as earlier noted, distress-related renegotiation typically results in very finely tuned contract protections for the bank. ${ }^{145}$ This sort of contract is likely to be substantially complete by the time a firm is in distress.

\section{Not All Creditors Would Agree to Creditor Duty}

Even assuming all credit contracts had gaps, creditors' conflicting interests make constructing a hypothetical Creditor Duty bargain impossible. By the time the firm is in distress, its creditors will enjoy differing rights (including payment and priority rights), differing stakes in the continuation of the borrower firm, and differing contract protections. Ex ante, each creditor will anticipate the varying ex post predicaments of creditors inter se. It is highly implausible, therefore, that every creditor would agree ex ante that creditors as a group should enjoy the benefit of managerial fiduciary duties. Creditor Duty has a leveling effect, granting all creditors fiduciary duty protections, creating leverage for some creditors that they would not otherwise enjoy. Creditors without explicit covenant protections would be able to object to certain transactions or other managerial acts. This would confer hold-out power on these creditors without necessarily improving creditor prospects generally. There is no reason to expect that creditors better situated by their actual contracts would agree to this arrangement. Moreover, this leveling effect of the hypothetical Creditor Duty contract is flatly contradicted by the actual contracts that parties write, as the theory of delegated monitoring explains.

Obligational incompleteness should be distinguished from "contingent incompleteness," which among economists refers to a contract that fails to fully realize the potential gains from trade in all states of the world. No contract is contingently complete. Some quibble exists as to whether any contract can ever be obligationally complete. See id. at $731 \&$ n. 10 .

144 See Roberts \& Sufi, supra note 103.

145 See supra Part II.B.1. 
Besides disagreement over the substantive default that Creditor Duty creates, each creditor's general preference for court-supplied gap fillingcourts' relative aggressiveness at finding contract gaps-will vary with the protections of its own credit contract. A creditor with stronger contractual protections would rather that courts not intervene. Banks will generally prefer their actual contract terms to court application of general default rules, and they will prefer that all creditors be left to the terms of their actual contracts. On this score as well, Creditor Duty fails. It creates a very strong default—one that logistically is very difficult to contract around. ${ }^{146}$ In effect, under Creditor Duty, all credit contracts invite judicial gap filling. Not all creditors would agree.

\section{Specific Problems for Hypothetical FVM Bargains}

\section{Basic FVM}

As earlier noted, in addition to traditional duty-shifting doctrine, scholars have suggested even more drastic revisions to the standard shareholdercentered view of fiduciary duties. Thomas Smith has proposed financial value maximization (FVM) - that managers' general charge should be to maximize the sum of the values of all financial claims on the firm, rather than simply effecting some shift in beneficiaries as the firm approaches insolvency. According to Smith, a rationally diversified investor would invest in the market portfolio. For any given firm, this investor would invest proportionally in all the capital assets issued by the firm. ${ }^{148}$ Therefore, the investor would be indifferent as to wealth transfers between the firm's stocks and its bonds, as long as the net result of any investment was to maximize the sum of the values of all the financial claims on the firm. Rational investors striking a hypothetical ex ante bargain over fiduciary duties would therefore agree that corporate managers should pursue financial value maximization, not shareholder value. And this expanded duty should apply all the time. For Smith, the "vicinity of insolvency" is incoherent. ${ }^{149}$ All firms are always in the

\footnotetext{
146 See infra Part II.E.2.

147 See Smith, supra note 7, at 217-18 (discussing the behavior of hypothetical rational investors).

148 See id.

149 Id. at 220.
} 
zone of insolvency because managers can always find a sizeable enough bet that puts all the firm's equity at risk. ${ }^{150}$

Besides the basic problems described above in trying to impute a hypothetical bargain among a heterogeneous bunch of creditors, FVM suffers an additional shortcoming. An FVM approach relies on the very strong assumption that rational investors hold the perfect market portfolio. Going beyond the common assumption of rational investor diversification, Smith assumes that all investors hold capital assets of each firm in exactly the proportions issued by the firm. ${ }^{151}$ Were that true, it would follow tautologically that investors would be indifferent as to wealth transfers between classes of a firm's securities. The assumption is so strong that it eliminates the problem entirely. If all investors hold capital assets in the exact proportions issued by each firm, then all interclass investor conflict disappears. Debt's priority over equity, for example, becomes meaningless under Smith's assumption, since each investor owns proportionate amounts of each class. With this assumption, the hypothetical contract analysis is pretty simple-in fact, too simple.

Of course, no investor actually holds the perfect market portfolio. Even financial economists acknowledge its impracticality. ${ }^{152}$ Conflict among classes of financial claims cannot be so easily assumed away. ${ }^{153}$ Investors certainly seek a diversified investment portfolio, but Smith artificially constrains investors' hypothetical investment choices to financial instruments, based on the notion that well-developed finance theory deals only with these sorts of investments. ${ }^{154}$ But real investors do not limit their investments to only those

$150 I d$. at 223. Smith's formulation is not necessarily limited to including creditors. Presumably, hybrid securities holders would count as holders of financial claims on the firm. Smith's discussion focuses primarily on creditors, though, so I emphasize that aspect in the above discussion of his proposal.

151 See supra note 65 and accompanying text.

152 See, e.g., Haim Levy, Equilibrium in an Imperfect Market: A Constraint on the Number of Securities in the Portfolio, 68 AM. ECON. REV. 643, 656 (1978) (noting that a perfect market portfolio does not conform to reality); Richard Roll, A Critique of the Asset Pricing Theory's Tests, 4 J. FIN. Econ. 129, 151 (1977) (suggesting that the perfect market portfolio is an unrealistic concept).

153 See supra note 20 and accompanying text.

154 Smith, supra note 7. As Smith notes:

Ideal CAPM investors in fact are diversified across all classes of capital assets and hold particular assets in proportion to the percent that the class of assets represents of the capital market as a whole. ... Since CAPM is the theoretical ground for using diversified investors in economic analysis of corporate law at all, it makes sense to model investors as complying with the CAPM mandate closely. To do otherwise would require some theoretical justification, and none is apparent. 
discussed in finance texts. Moreover, their ideal asset portfolios often depend on what their liabilities look like. A quick look at garden variety institutional investors gives lie to Smith's assumption. Insurance companies, for example, select financial investments in order to match their policy liabilities. This matching strategy assures that their investment portfolios cannot take the flavor Smith assumes. They are not interested so much in the theoretical market portfolio as a long-term portfolio that offsets their generally long-term policy liabilities. ${ }^{155}$ Pension funds-which collectively hold about $25 \%$ of U.S. market capitalization ${ }^{156}$ - follow similar liability-matching strategies. ${ }^{157}$ Given that these two important types of institutional investor do not hold the market portfolio (nor do they even attempt to), crafting policy prescriptions based on Smith's assumption seems ill-advised.

Because investors do not generally hold the market portfolio, they will not be indifferent to wealth transfers across different classes of the firm's securities. So the hypothetical bargain underpinning Smith's FVM approach fails. Moreover, FVM suffers from the same affliction as other Creditor Duty approaches-it ignores the actual contracts parties write. If investors actually

Id. at $241-42$.

155 Anthony Saunders \& Marcia Millon CoRnett, FinAnCial Institutions Management: A Risk MANAGEMENT APPROACH 69 (5th ed. 2006) (showing distribution of assets of U.S. life insurance companies). For example, in 2003, U.S. life insurers held $11.7 \%$ of their assets in government securities, $41.8 \%$ in corporate bonds, $27.8 \%$ in stocks, $6.8 \%$ in mortgages, $2.7 \%$ in policy loans (loans to policyholders secured by the policies themselves), and $9.2 \%$ in miscellaneous U.S. assets. Id. tbl. 3-2.

156 Josef Lakonishok et al., Window Dressing by Pension Fund Managers, 81 AM. ECON. REV. (PAPERS \& PROC.) 227, 227 (1991).

157 [T] here are a variety of constraints which apply to life insurers or pension funds, all of which may have a marked effect on optimal portfolios, even abstracting from regulation. Notably, the nature of the liabilities is the key to understanding how institutional investors differ in their operations....

... [S]olvency considerations for insurance companies and defined benefit pension funds typically require a focus on shortfall risk and asset liability management rather than simple riskreturn optimization. As a consequence, for these types of institutions, the optimality of portfolio choices cannot readily be judged by simple measures such as the mean and standard deviation of the real return.

E. Philip Davis, Portfolio Regulation of Life Insurance Companies and Pension Funds 4-7 (Pensions Inst. Discussion Paper PI-0101, 2001), available at http://www.pensions-institute.org/workingpapers/wp0101.pdf. Many mutual funds also consciously choose not to hold the market portfolio. Instead, they hold only a particular type of security_-government bonds, corporate bonds, or corporate equities, for example. Or they may specialize in small-cap or mid-cap companies or real estate companies. One might argue, though, that these institutions are merely investment vehicles for "end-users," who might indirectly aim to hold the market portfolio through mutual fund holdings. Even if this is right-which is unlikely-it should be clear from the above discussion that Smith's assumption that rational investors hold the market portfolio is a heroic one. 
held the market portfolio and were indifferent to distributional issues, credit contracts would look very different from the way they do. Even a casual glance at actual credit contracts shows that creditors are not indifferent to distributional issues. Bank credit agreements and bond indentures are chock-ablock with terms evidencing creditors' distaste for investments by the borrower or distributions to its shareholders that imperil the borrower's ability to repay its debt. ${ }^{158}$ These provisions are not designed to assure that managers make financial-value maximizing decisions; they are designed to constrain managers' ability to favor equity holders at creditors' expense. ${ }^{159}$

\section{FVM-Plus-Performance-Creditors}

Alon Chaver and Jesse Fried are in sympathy with Smith's FVM approach, though they find it incomplete in one important respect. It fails to include performance creditors-parties owed contractual performance from the firmin the maximization calculus. ${ }^{160}$ For Chaver and Fried, once the firm's financial condition justifies inclusion of creditors under the protections of managerial fiduciary duties, those creditors should include performance creditors as well as Smith's financial creditors. Otherwise, managers may make inefficient decisions in pursuit of FVM. They might invest with a view to maximizing financial value, but at the same time damage the firm's ability to perform its contracts, causing more harm to performance creditors than benefit to financial claimants. ${ }^{161}$

The infirmity of Smith's hypothetical FVM bargain causes problems as well for Chaver and Fried's "FVM-plus-performance-creditors" approach. If the FVM hypothetical bargain fails, then adding performance creditors seems not to improve matters on that front. Chaver and Fried do not explicitly offer a hypothetical bargain rationale for their approach, though they do argue that shareholders would benefit ex ante from their approach, since performance

158 See supra Part II.A.3, II.B.1.

159 Smith doubts that the terms of actual contracts can tell us much about what shareholders or creditors want because creditors cannot contract for fiduciary duty protections or "similar protection." See Smith, supra note 7 , at 251. Both the premise and the conclusion are questionable. As I detail below, creditors can and do contract for all kinds of protection from managers hell-bent on maximizing share value, including primacy over shareholders. See infra Part III.C. In addition, as the text describes, actual contracts offer pretty good reason to doubt that investors generally hold the market portfolio in the way Smith describes. Credit contracts evidence that creditors care about distributional issues.

160 See Chaver \& Fried, supra note 7, at 1825.

161 Id. at 1826. 
creditors thus protected would offer better contract terms. ${ }^{162}$ In other words, maximizing the sum of the values of all financial and performance claims on the firm would be efficient, which is good for everyone. Who can argue against efficiency?

In fact, a hypothetical-bargain approach here would be difficult. Smith's hypothetical bargain depended on the assumption that all investors hold the market portfolio. It would be an even more heroic assumption-which Chaver and Fried do not make - to assert that all investors hold proportionate interests in all claims on the firm, including claims on the firm's performance of its various contract obligations. So whether Chaver and Fried's fiduciary formulation is theoretically efficient or not, it is quite difficult to square with a hypothetical bargain approach to the extent it depends on investors' (including performance creditors) indifference to each firm's distribution of gains across classes of claimants.

Moreover, assuming performance creditors are not indifferent to distributional issues, the protection of the "FVM-plus-performance-creditors" formulation seems rather weak. Performance creditors receive no assurance that managers will not distribute value from them to shareholders or other creditors, only that when managers do so, the gains to other claimants will exceed the harm to performance creditors. Performance creditors would still need to protect themselves from excessively shareholder-focused managers by resorting to explicit contract terms. Like financial creditors, performance creditors do often rely on contractual protections that obviate the need for any judicially imposed fiduciary duty. Performance bonds and standby letters of credit-as well as the use of multiple suppliers-are familiar devices that performance creditors use to shift the risk of nonperformance. Firms and their performance creditors can readily insure against the risk that Chaver and Fried fear.

\section{E. Costs of Creditor Duty}

Creditor Duty is not free. In addition to the conceptual problems of trying to conjure Creditor Duty from a hypothetical bargain framework, Creditor Duty is costly. Expanding managers' fiduciary duties to embrace creditors creates inefficiencies of its own.

162 See id. at 1843. 


\section{Increasing Litigation and Caution Costs}

Whether the Creditor Duty rule is creditor primacy, as current doctrine generally suggests, ${ }^{163}$ or some shared duty to creditors and shareholders, as other courts and FVM proponents argue, ${ }^{164}$ beneficiaries of the duty necessarily have conflicting interests. ${ }^{165}$ Many managerial decisions will therefore unavoidably harm some class of beneficiaries, who may sue. Even for a transaction that enhances value overall, a specific creditor who suffers diminution in the value of its claim may sue. The business judgment rule ordinarily insulates managers' decisions from challenge in the absence of fraud, illegality, or conflict of interest. ${ }^{166}$ But the scope of that insulation seems unclear in the Creditor Duty context. For example, any transaction plausibly benefiting shareholders at creditors' expense might be framed as a conflict of interest, since directors depend on shareholders' votes to retain their board seats. ${ }^{167}$ This removes the decision from the protection of the business judgment rule, subjecting it to substantive evaluation. ${ }^{168}$

In that case, whether the Creditor Duty is strictly to creditors or demands value maximization, the litigation would likely require expensive proceedings to determine the value to various constituencies of the challenged transaction. ${ }^{169}$ The insolvency requirement to duty-shifting under existing law

163 See supra notes $46-47$ and accompanying text.

164 See supra notes 52-57 and accompanying text; see also supra Part I.C.

165 By contrast, shareholder interests can be thought of as unitary, such that shareholder primacy does not generally implicate similar issues of unavoidable conflict. See supra note 86 and accompanying text.

166 Stephen M. BAinBRidge, CoRPoration LAW AND ECONOMiCs $§ 6.4$ (2002).

167 Cf. Claire A. Hill \& Brett H. McDonnell, Disney, Good Faith, and Structural Bias, 32 J. CoRP. L. 833, 837 (2007) (explaining Delaware's intermediate standards of review for takeover defenses, Revlon auctions, and special committees' dismissal of demand-excused derivative suits, all of which involve situations where directors may not have the narrow self-interest traditionally required for strict duty of loyalty analysis, and yet potential structural bias makes business judgment rule deference also inappropriate).

168 Similarly, raincoat statutes like Delaware's section 102(b)(7)-insulating directors from money damages for breach of fiduciary duty—typically exclude duty of loyalty violations. DEL. GEN. CORP. L. $\S 102$ (b)(7) (2008).

169 With creditor primacy, a disgruntled creditor would probably have to argue that the transaction impermissibly elevated shareholder interests above those of creditors. With an FVM rule, an objecting creditor would argue that the harm to creditors exceeded any gain to shareholders. See supra note 66 and accompanying text. Of course, given heterogeneous creditors, not all would necessarily be harmed by the transaction or object to it; some may even gain from it. The prospect of multiparty litigation over valuation issues merely exacerbates the costs described in the text.

Chaver and Fried and Smith each attempt to abstract away from enforcement issues. See Chaver \& Fried, supra note 7, at 1815 n.7 ("Our own view is that judicially articulated fiduciary duties, even if they are unenforceable, can influence managerial behavior by affecting social norms. .. . [T] his Article abstracts from the question of how fiduciary duties affect managers' decisionmaking . . . to focus on what the content of those 
adds another litigable valuation issue. Valuation litigation is notoriously costly, in terms of both out-of-pocket expenditures and unpredictability. ${ }^{170}$ It typically requires extensive analysis and testimony by competing experts, with each interested party fielding its own experts. ${ }^{171}$ Consider Thomas Smith's financial value maximization approach. ${ }^{172}$ Assuming a simple capital structure with only bonds and common shares, any disgruntled bondholder might assert that a given transaction caused more aggregate harm to bondholders than aggregate benefit to shareholders. ${ }^{173}$ Measuring the total harms and benefits might not be a simple task even in that simple case. ${ }^{174}$ Now throw in some secured creditors. The transaction's effects on their claims would also have to be valued for FVM purposes. Depending on the type and value of their collateral, some secured creditors might benefit from the transaction; some might not. ${ }^{175}$ It is not hard to imagine multiparty valuation litigation, where every party has experts testifying on the value of every other party's claims.

Now add performance creditors according to Chaver and Fried's FVMplus-performance-creditors approach. Recall their fear that at or near insolvency, managers may inefficiently underinvest in the firm's ability to perform its contractual obligations, thereby harming parties owed contract performance from the firm. Set aside for the moment any balancing issues with financial claimants. Imagine just having to peg the current value of the future harm to the firm's contracting partners from current underinvestment that may later result in the firm's performance failure. Chaver and Fried use the example of a distressed firm considering laying off an engineering group

duties should be."); Smith, supra note 7, at 264 ("Throughout this Article, I have deliberately spoken in terms of a corporate law 'norm.' A norm is not necessarily a rule that one can enforce in court."). However, these attempts are unsatisfying. Smith relies on an idealized enforcement analysis to argue that FMV would be an equilibrium even without his CAPM rational investor analysis. Id. at 265-66. Chaver and Fried cite transaction costs, nonobservability and nonverifiability of investment levels, and other impediments to actual renegotiation in asserting the superiority and necessity of their idealized Creditor Duty approach. See Chaver \& Fried, supra note 7, at 1837-41. Moreover, selective ignoring of enforcement issues also ignores the possibility that Creditor Duty "norms" are more costly than competing norms.

170 Keith Sharfman, Valuation Averaging: A New Procedure for Resolving Valuation Disputes, 88 MiNN. L. REV. 357, 377 (2003).

171 Id. at 358-59 (discussing "dueling experts" phenomenon).

172 See supra note 66 and accompanying text

173 This value-decreasing deal by definition cannot maximize financial value among shareholders and bondholders.

174 Market values might be useful, but they fluctuate both in the short- and long-term. Fights over valuation methodology would likely accompany the inevitable fights over bottom line conclusions.

175 For example, if one creditor's collateral is real estate and another's is inventory, the effects of a given transaction might be very different for the two creditors. 
that might later be needed to produce a promised software update. ${ }^{176}$ How much harm will the layoff do to performance creditors-i.e., the firm's customers? Answering that question would require analysis of the value to each customer of having the update sometime in the future. Depending on the uniqueness of the software and whether a close substitute exists-factors which may vary by customer-the measure of harm would likely vary by customer. In addition, some assessment would have to be made of the likelihood that the engineering group would later be needed to produce the update. One would want to discount the total expected harm if no update were produced by the likelihood that the engineering group would not be needed to produce it. The calculus is not simple. Litigating over this probabilistic assessment would be expensive. And this is before we even get to the balancing of harms and benefits with financial claimants. Finally, the pool of potential plaintiffs is vast. Any customer especially in need of the future update enjoys standing under Chaver and Fried's proposal to sue managers for a breach of fiduciary duty. And this right of action accrues even before the firm has breached its contract, and even if the firm never breaches!

With the expanded field of potential plaintiffs that Creditor Duty creates, managers would tend to be overcautious. They might avoid value-enhancing transactions whose distributional consequences might invite challenge. They would spend more time and resources documenting whatever decisions they made. Even for important but uncontroversial transactions, they might have to make at least token efforts to evaluate the effects on all potential plaintiff constituencies. These costs of caution may be especially pernicious because they are often difficult to observe or measure. The costs of foregone transactions are especially problematic in this regard. And with Smith's FVM, unlike insolvency-based duty-shifting, the expanded fiduciary duty would apply all the time, so that the costs of caution would affect even transactions of healthy firms.

All of these costs operate essentially as a tax on credit. Borrowing costs increase; creditors' collection costs increase. Creditors will attempt to recoup these increased costs in the pricing of their credit, of course. None of this is to suggest that private contracting entails no enforcement or other costs. However, private contracts enable parties to tailor their constraints for a specific firm in a specific situation. Any litigation is likely to involve more narrow issues than the value to the creditor of a transaction of the borrower

176 Chaver \& Fried, supra note 7, at 1831. 
firm. Private contracts will also involve a relative handful of parties, so the pool of potential plaintiffs is likely to be small. I discuss the costs of private contracting more fully in the next Part. ${ }^{177}$

\section{Creditor Duty's Strong Default}

Unfortunately, these conflict problems with Creditor Duty cannot easily be resolved by negotiation. Giving leverage to all creditors, Creditor Duty unavoidably complicates the prospects of pursuing efficient transactions that may harm some creditors. ${ }^{178}$ Creditor Duty not only confers holdout power to creditors, but confers it so widely that contracting around Creditor Duty is well-nigh impossible. A blanket entitlement for creditors requires firm managers to negotiate affirmative permission from each creditor in order to pursue an efficient project. ${ }^{179}$ In effect, Creditor Duty creates a very strong default, one very difficult and costly for the parties to contract around. ${ }^{180}$

Standard holdout problems would arise, but there is more. Given that under current law, the firm's financial condition is crucial to the determination of whether creditors are owed any duty, managers may be reluctant to seek such permission, as it might either signal publicly the firm's shaky condition or prejudice managers in later litigation over the firm's solvency and the issue of whether a fiduciary duty shift had been triggered. In addition, with an expansive Creditor Duty-created universe of potential holdouts whose consent would be required, confidentiality concerns might doom any deal.

Compared to the overinvestment problem under a shareholder primacy rule, this Creditor Duty inefficiency is likely to be much more difficult to negotiate around ex post. To curb overinvestment under shareholder primacy while permitting efficient investment requires only one creditor-albeit a relatively

177 See infra Part III.E.

178 While a truly efficient transaction is not actionable by creditors under FVM-since by definition the gain to shareholders from an efficient transaction would exceed any harm to creditors-valuation is always expensive and difficult to predict. The threat of valuation litigation may preclude marginally efficient deals.

179 Perhaps small creditors could simply be paid off. But the risk of preference avoidance in bankruptcy may discourage some creditors from taking payment to let the project go through. See supra notes 137-39 and accompanying text (discussing preference avoidance).

180 See Ian Ayres \& Robert Gertner, Filling Gaps in Incomplete Contracts: An Economic Theory of Default Rules, 99 YALE L.J. 87, 119-25 (1989) (noting that varying levels of effort required to contract around default rules also determine when a "gap" exists for courts to fill). A low threshold for contracting out results in a "weak" default. Conversely, a high threshold creates a "strong" default—one that is difficult to escape by explicit contract. In either case, failing to contract out allows a court to fill the "gap" with ex post application of the default rule. $I d$. 
sophisticated one-to negotiate (or renegotiate) contractual limitations on management. This seems to occur frequently. ${ }^{181}$

\section{F. Summary}

Corporate fiduciary duties are relatively broad and general, with courts getting involved to flesh out the duties in specific contexts. This approach is appropriate for solving the enormous contracting problem faced by shareholders, especially given shareholders' unitary interest. ${ }^{182}$ Creditors do not suffer similar contracting problems, and their interests are far from unitary.

Creditors' varied risk preferences and contract protections make a hypothetical multiparty Creditor Duty bargain highly implausible. It is hard to see why sophisticated bank creditors with elaborate contract protections would subscribe to a hypothetical Creditor Duty bargain that adds nothing to-and probably detracts from-the actual bargains they already enjoy. Moreover, creditors' varied monitoring capacities explain why not all credit contracts look like the bank's. The differences do not necessarily suggest gaps in credit contracts. The theory of delegated monitoring explains why even absent transaction costs, credit contracts would vary as they now do. Neither existing duty-shifting doctrine nor proposals for its expansion can be justified under the standard incomplete contracts approach to corporate fiduciary duty. Creditors would not agree.

181 These costs of Creditor Duty may be especially pernicious because it is unclear that overinvestment presents a real problem. The prevalence of bank debt among public companies, with its protective covenants, should offer some comfort that private constraints operate to curb overinvestment. See supra note 128 and accompanying text. In addition, the empirical evidence on overinvestment by distressed firms is mixed. See Barondes, supra note 71, at 59 (reviewing empirical literature). It may be that managerial self-interest trumps any desire to bet the company in order to secure a return to shareholders. Managers interested in prolonging their tenure as managers would more likely pursue a conservative investment strategy, aiming for survival, rather than taking a spectacular do-or-die bet. See, e.g., Hu \& Westbrook, supra note 49, at 1378-79 (contending that a company's financial trouble exacerbates management's natural inclination "to take care to take care"). But if this is right, then overinvestment is not a serious problem to begin with.

In addition, courts' resort to the duty-shifting doctrine to date has not been to police inefficient investment decisions - as the finance canon might suggest. Instead, the rule has been used more as an equitable makeweight. Courts have piled on the duty-shifting burden only after managers' conduct toward creditors is sufficiently unsavory that several other causes of action are also clearly available-fraud or fraudulent transfer or veil piercing, for example. See, e.g., Prod. Res. Group, L.L.C. v. NCT Group, Inc., 863 A.2d 772 (Del. Ch. 2004) (holding that a creditor's complaint for breach of fiduciary duty should survive dismissal because it presented facts that suggested that the directors of the company were acting in self-interest and bad faith). To the extent that equitable considerations may motivate duty-shifting, these other creditorprotective doctrines would seem sufficient. See generally Lipson, supra note 87 (noting special vulnerability of creditors with low volition, cognition, and exit opportunities).

182 See supra note 86 and accompanying text. 
A world without Creditor Duty is not especially troubling, however. Private contracts often include provisions to curb overinvestment, especially when the firm is in distress. One creditor's monitoring efforts are sufficient in this regard; other less vigilant or less sophisticated creditors benefit from the sophisticated creditor's vigilance. Moreover, Creditor Duty creates its own costs, which likely dwarf the costs of overinvestment.

\section{CONTRACT PRIMACY}

Rebutting Creditor Duty attacks on shareholder primacy does not end my project, which is not intended to render shareholder primacy inviolable, but to renew our faith in the contracts parties actually write. In particular, credit contracts often contain provisions to curb or modify shareholder primacy and thereby curb overinvestment. We have seen the difficulty of constructing a hypothetical contract between shareholders and creditors to abrogate shareholder primacy, as well as the costs of such a fiduciary rule. ${ }^{183}$ However, shareholders-through their manager-agents - and specific creditors should be permitted to make actual contracts to modify the traditional rule. The parties are better situated ex ante to identify the situations in which perverse investment incentives may operate, and to craft tailored mechanisms in response, than are courts scrutinizing ex post. Sometimes these situations will demand only negative constraints, as discussed earlier. ${ }^{184}$ Other times, more drastic measures may be required. In effect, specific creditors should be able to obtain fiduciary duty-type protections-creditor primacy-as a matter of contract. Moreover, given the conceptual infirmities of hypothetical bargain analysis for Creditor Duty, actual contracts are all we have.

Creditor Duty may be driven by a misperception that private contracting cannot be relied upon to curb managerial overinvestment, either because of contracting failures ${ }^{185}$ or the belief that managers' duty of loyalty to shareholders is a mandatory rule that cannot effectively be contracted around. "Commentators routinely assert that ... the duty of loyalty is nonwaivable.", 186 In this Part, I address these doubts about private contracting.

183 See supra Part II.E.

184 See supra Part II.A.3.

185 See Chaver \& Fried, supra note 7, at 1838 (discussing difficulty of renegotiation).

186 Macey, Fiduciary Duties, supra note 41, at 1277; see also Smith, supra note 7, at 251 ("In practice, bondholders cannot contract into fiduciary or similar protection as a gap-filling rule that is superior to what shareholders get, whether or not they wanted to do so. Bondholders could not get a contractual term that says, 'for all matters not addressed in this contract, the interests of bondholders are to be treated by corporate 
We have already noted banks' special expertise in anticipating and responding to borrower financial distress with covenant protections specifically addressed to overinvestment. ${ }^{187}$ With the pervasive use of bank debt by public companies, we have reason to expect that private contracting will often be effective in curbing overinvestment. ${ }^{188}$ In some cases, creditors have gone further, successfully implementing arrangements for creditor voice or even creditor primacy. Creditors have designed management structures to assure managerial allegiance to them. In effect, creditors and their borrower firms are contracting out of shareholder primacy.

Courts have vindicated these arrangements and resulting pro-creditor management decisions. However, these courts remain tethered to existing duty-shifting doctrine requiring the firm's insolvency in order to enforce private contracts. I argue that the doctrine should be discarded.

This Part explains contract primacy as follows. Part III.A reasserts the case for shareholder primacy, but only as a default. Part III.B addresses the misperception that managers cannot contract away their fiduciary duties to shareholders. Part III.C shows contract primacy in action for creditors. Part III.D argues for the abandonment of existing duty-shifting doctrine in favor of private contract. Finally, Part III.E explains why private contracting is likely to be more efficient than Creditor Duty.

\section{A. The Shareholder Primacy Default}

Insolvency-based duty-shifting doctrines, along with Creditor Duty proposals, illustrate the weakness of the residual claim argument for shareholder primacy. ${ }^{189}$ While shareholders may still most commonly

\footnotetext{
directors as equal to (or superior to) those of common shareholders.' As interpreted by modern courts and academic commentators, such a provision would violate managers' fiduciary duty to shareholders. . . . [A]s long as the governing rule is that shareholders benefit exclusively from a fiduciary duty and bondholders can get only express contractual protections, a contract term purporting to provide bondholders with something like gap-filling fiduciary protection would be unenforceable."); see also Fried \& Ganor, supra note 5, at 1014 ("[C]orporate fiduciary law is considered mandatory and not contractually alterable. Thus, parties who would prefer some other approach to corporate fiduciary duty are unlikely to try to contract for it.") (footnote omitted).

187 See supra Part II.A.3, II.B.1.

188 See supra note 128 and accompanying text.

189 Scholars have noted more generally the vagueness of the debt-equity distinction. See Hu, supra note 6, at 1289 (noting similarity of junk bonds to common stock); Katherine Pratt, The Debt-Equity Distinction in a Second-Best World, 53 VAND. L. REV. 1055 (2000) (discussing elimination of the debt-equity distinction for income tax purposes). The increasing issuance of hybrid securities further highlights this indeterminacy of residual claimant status. See Hu, supra note 6; Partnoy, supra note 6.
} 
constitute a firm's residual claimants, this qualified observation is insufficient to justify a blanket rule of shareholder primacy. Similarly, shareholders may generally value fiduciary duties more highly than creditors and other nonshareholders, but in some instances, specific constituents would be willing to buy off shareholders' privileged position. ${ }^{190}$

However, shareholder primacy is justifiable as a default rule, as a first approximation of the efficient fiduciary rule. It comes out of the original shareholder contract: shareholders are the corporation's original residual claimants, in both an economic and legal sense. The original corporate contract requires shareholders, but not other claimants. As the initial residual claimants, shareholders necessarily have severe contracting problems not suffered by other claimants, ${ }^{191}$ who draft actual contracts to structure their relations with the firm. These non-shareholder contracts may be incomplete; they may have gaps. But creditors and other claimants often fill gaps in their specific contracts with the firm privately through renegotiation. To the extent gaps remain, the gaps should be filled with standard gap filling devices, but not with corporate fiduciary duties. As the original residual claimants suffering this initial problem of open-ended relations with firm management, shareholders value and demand the benefit of managerial fiduciary duties.

Over the life of the corporation, however, situations may arise in which it makes sense for shareholders - through their agent-managers-to contract away their favored position. Against the conventional wisdom, shareholders should be able by contract to voluntarily "sell" their favored position because other parties may value the position more. A specific creditor may in some circumstances wish to contract for affirmative corporate governance protections, exercising positive control over firm management instead of mere negative control by contract.

Treating shareholder primacy as merely a default respects parties' ability to tailor fiduciary duty by contract. It is consistent with the nexus-of-contracts view of the corporation. The shareholder contract as initially conceived has no sacred status. ${ }^{192}$ It should be subject to contractual modification.

\footnotetext{
190 Macey, Economic Analysis, supra note 80, at 30-31; Macey, Fiduciary Duties, supra note 41, at 1274.

191 See supra Part I.A.

192 Bainbridge explains:

In the nexus of contracts theory, there is nothing unique about the shareholder-corporate relationship. Shareholders do not own the corporation and, accordingly, directors are not
} 


\section{B. Contracting for Primacy}

Conventional wisdom holds that managers' fiduciary duty of loyalty to shareholders is mandatory and nonwaivable. ${ }^{193}$ While there is some truth to this conventional view-managers cannot simply contract away their duty of loyalty wholesale-they can, do, and must in piecemeal fashion. Managers make all sorts of commitments for their firms that circumscribe their later discretion to favor shareholders. Only what is left of managerial discretion remains to be exercised for shareholders' benefit. ${ }^{194}$ In that sense, and contrary to the conventional wisdom, managerial fiduciary duties are contractible. Every contract commitment "contracts away" fiduciary duties insofar as it constrains managers' subsequent discretion to pursue shareholder value.

Creditors often contract with managers for arrangements that impinge on shareholder primacy. For example, bank loan agreements often restrict firm investment policy with restrictions on capital expenditures. ${ }^{195}$ Such a restriction may later operate to preclude a project that shareholders would otherwise have preferred. When managers originally decided to accede to this restriction, of course, they presumably considered the various trade offs involved - tighter covenants versus higher interest rate, for example-and concluded that the terms were in shareholders' best interest. The arrangement may turn out to have been less than optimal ex post, but every contract carries that risk. Through these contract terms, creditors enjoy direct influence over fundamental management decisions-influence that corporate law denies to shareholders. ${ }^{196}$ Managers explicitly subordinate their duty of loyalty to shareholders to the rights of contracting parties. Managers' latitude to pursue shareholder interests in the future is constrained.

stewards of shareholder wealth. Shareholders are simply a group of participants bound together by a web of voluntary agreements whose nexus the law treats as a firm.

Bainbridge, supra note 35, at 551.

193 Am. Law Inst., Principles of CoRporate Governance: Analysis and ReCOMmendations § 7.19 (reporter's note 5) (2005); see also Melvin A. Eisenberg, The Structure of Corporation Law, 89 CoLUM. L. REV. 1461, 1481 (1989) ("[T]he corporation's directors and officers have a duty of loyalty to the corporation that cannot be substantially altered."). But see Easterbrook \& Fischel, Contract and Fiduciary Duty, supra note 11 (noting the contractual nature of fiduciary duties and that "[a]ctual contracts always prevail over implied ones").

194 Jonathan Macey has explained this residual character of managers' duty to shareholders. See Macey, Fiduciary Duties, supra note 41.

195 See supra notes 125-27 and accompanying text.

196 Shareholders have no say, for example, over the firm's investment policy. "[S]hareholders lack either direct or indirect mechanisms of control." Bainbridge, supra note 35, at 572. 
Sometimes, these contract constraints include more than simple limits on managers' discretion. For example, non-shareholder constituents may contract for representation inside the firm's management structure, even to the point of taking control of the firm. Banks often contract for the right to appoint a representative to sit on a borrower's board of directors. ${ }^{197}$ The purpose for the bank designee is presumably not to protect shareholders' interests, but the bank's. Less modestly, creditors have negotiated for appointment of their own designees to manage borrower firms. Creditor-appointed managers have made decisions favoring creditors over shareholders, and courts have approved these decisions. In the famous Credit Lyonnais case, ${ }^{198}$ which I discuss in the next section, bank and borrower negotiated a comprehensive Corporate Governance Arrangement that, among other things, appointed the bank's designee as CEO. Douglas Baird and Bob Rasmussen also describe in detail the rise of the chief restructuring officer ( $\mathrm{CRO})$, the bank's designee to run the distressed borrower firm if existing management fails to turn the company around. ${ }^{199}$ The CRO appointment is now common practice, as the culmination of the process of banks' gradual easing of the reins from the management of defaulted borrowers.

Even contracts giving creditors control of the firm may be in the best interests of the common shareholders. If the alternative is immediate liquidation, the common are likely better off allowing creditors to control the firm in an attempt to salvage value. In principle, these contracts are not qualitatively different from firms' run-of-the-mill contracts commitments, which also circumscribe managers' latitude to pursue shareholder value.

Courts have validated these arrangements in a qualified way. They have upheld management decisions favoring creditors at shareholders' expense, but have insisted on the firm's insolvency, according to existing duty-shifting doctrine. To these cases we turn.

197 Stuart C. Gilson, Bankruptcy, Boards, Banks, and Blockholders: Evidence on Changes in Corporate Ownership and Control when Firms Default, 27 J. FIN. ECON. 355, 356 (1990) (finding that banks frequently appoint directors to public company boards once the borrower has defaulted); Randall S. Kroszner \& Philip E. Strahan, Bankers on Boards: Monitoring, Conflicts of Interest, and Lender Liability, 62 J. FIN. ECON. 415, 416 (2001) (noting that "one third of large U.S. firms do have a banker on the board").

198 Credit Lyonnais Bank Nederland, N.V. v. Pathe Commc'ns Corp., No. 12,1240, 17 DEL. J. CoRP. L. 1099, 1991 WL 277613 (Del. Ch. 1991).

199 Douglas G. Baird \& Robert K. Rasmussen, Private Debt and the Missing Lever of Corporate Governance, 154 U. PA. L. REV. 1209, 1233-34 (2006). 


\section{Actual Contracts}

This section presents two examples of contracts for creditor primacy. Courts have approved these arrangements favoring creditors over equity holders, laboring somewhat to adhere to the existing duty-shifting framework. The decisions suggest, however, that parties' expectations-derived from the content of their specific arrangements-drive decisions. I discuss only two cases - one of which involves not a corporate borrower, but a Delaware limited liability company. My goal is not to show the universality of contract solutions when shareholder primacy is or may become inefficient, but more modestly to demonstrate that contracting for creditor primacy does occur, despite the conventional view of shareholder primacy's mandatory nature. ${ }^{200}$

\section{The Corporate Governance Arrangement in Credit Lyonnais}

From an incomplete contracts perspective, it is ironic that Credit Lyonnais should be the touchstone case for any Creditor Duty discussion. ${ }^{201}$ Credit Lyonnais was not a case crying out for judicial gap filling. Quite the opposite. By the time the case descended into litigation, the parties had completed their own contract with a tailor-made governance arrangement placing the dominant bank creditor in control.

The case involved a workout between sophisticated parties-an international bank and a publicly traded borrower. The parties devised a comprehensive management arrangement to govern for the duration of their workout. ${ }^{202}$ Credit Lyonnais (the "Bank") was a major lender to both MGMPathe Communications (MGM) and its publicly traded parent Pathe

200 Two Delaware cases similarly illustrate respect for private contract in the preferred shareholder context, affirming preferred-controlled boards' discretion to favor preferred shareholders at the expense of the common. See Orban v. Field, 23 DEL. J. CoRP. L. 335 (Del. Ch. 1997) (permitting a preferred-controlled board to sell the company for a consideration that left nothing for common shareholders); Baron v. Allied Artists Pictures Corp., 37 A.2d 653 (Del. Ch. 1975) (permitting a preferred-controlled board to prolong its tenure somewhat by not immediately paying accumulated arrearages on preferred dividends and acknowledging that, while the preferred board must serve the corporation and common shareholders as well, it may serve "those by whom it was put in office").

201 Credit Lyonnais, 17 DEL. J. CORP. L. 1099. Though Chancellor Allen's important discussion of managers' perverse incentives is largely confined to a footnote and though Credit Lyonnais remains officially an unpublished opinion, it is widely regarded as the seminal judicial explication for expanding duty-shifting into the vicinity of insolvency in order to regulate managers' investment decisions. Hu \& Westbrook, supra note 49, at 1337. Later courts explicitly adopt the analysis in Chancellor Allen's dictum, though for Delaware, a recent supreme court decision rejects a vicinity-of-insolvency expansion of fiduciary duties to creditors. See supra note 56 and accompanying text.

202 Credit Lyonnais, 17 DEL. J. CORP. L. at 1103-04, 1117-18. 
Communications Corporation (PCC). The Bank's loans were secured by a controlling block of MGM stock. When MGM was forced into bankruptcy by its trade creditors, the Bank agreed to finance MGM's exit from bankruptcy, but with conditions. The Bank agreed to forbear from foreclosing on its stock pledge and taking explicit control of MGM, and the parties negotiated a Corporate Governance Agreement (CGA). It set out a comprehensive scheme for management of MGM, including appointment of Alan Ladd-the Bank's choice-for chairman and CEO. ${ }^{203}$ The CGA also called for the formation of an executive committee, comprised of Ladd and his choice of COO-"to which all corporate powers and duties permitted by law ... to be delegated ... shall be delegated exclusively." 204

To insure compliance with the CGA, the Bank obtained the right to vote its controlling block of MGM stock pursuant to a voting trust. The Voting Trust Agreement was placed in escrow, and the Bank was given sole discretion to break the escrow to render the voting trust effective. ${ }^{205}$ PCC's controlling shareholder Giancarlo Parretti acceded to these arrangements. ${ }^{206}$

Ultimately, Parretti breached the CGA by attempting to wrest control from the CGA-created management structure. ${ }^{207}$ The Bank terminated the escrow on the voting trust and exercised its voting power to remove Parretti and his confederates from the board of directors. ${ }^{208}$ The Bank followed with a suit for a judicial determination that its elected board was the rightful board of MGM. ${ }^{209}$

$203 I d$. at 1103.

204 Id. at 1141. Board resolutions implementing the CGA also noted that while both members of the executive committee constituted a quorum, in the event of a vacancy on the committee, "the remaining member shall constitute a quorum." Id. The power to file bankruptcy, issue securities or appoint or remove the chairman and CEO were reserved to the board and would require a vote of four of the five directors. Id. at 1118 .

$205 I d$. at 1122 n.25.

206 At Parretti's insistence, the CGA also included explicit "exit" strategies for MGM-conditions under which the CGA would terminate, thereby ending the Bank's influence over the firm's management. In particular, Parretti negotiated for a provision that he needed only the votes of his own designees on the board of directors to cause the corporation to issue securities if the proceeds were used to retire the bank's debt. In effect, Parretti could buy out the bank's debt if he could find equity investors. Id. at 1119. "This point was significant. It meant that, if Parretti could find equity investors, he could use their investment to pay down debt and remove the bank from the picture, without having to involve the bank-designated directors or the executive committee comprised of the same individuals." Id.

207 Id. at 1130-31.

208 Id. at 1137.

209 Id. at 1103. 
In this suit, Parretti claimed that CEO Ladd and his executive committee breached their fiduciary duty to MGM's shareholder-parent PCC by failing to facilitate asset sales that Parretti sought in order to raise capital to pay off the Bank and regain control of MGM. The court rightly gave short shrift to this argument, finding that Ladd's management team had acted properly. ${ }^{210}$ The opinion is not surprisingly couched in Creditor Duty language. Chancellor Allen explicitly extended existing insolvency-based duty shifting into the "vicinity" of insolvency. In that area, he asserted, the board was not merely an agent for shareholders, "but owes its duty to the corporate enterprise", 211 and to the corporate "community of interests" that includes creditors. ${ }^{212}$ Management acted appropriately under this standard. It could reasonably suspect that under the circumstances, Parretti might accept fire-sale prices for the firm's asset. ${ }^{213}$

The vicinity-of-insolvency analysis seems largely superfluous ${ }^{214}$-if not pernicious ${ }^{215}$ - given the actual terms of the contractual arrangement between the Bank and MGM. The Bank retained veto rights over significant asset sales in any event ${ }^{216}$ - a standard term in credit agreements, and one that gets tightened as a matter of routine in workout. Even absent a Bank veto, Parretti could hardly have expected that Ladd or the management structure created at the Bank's behest would do his bidding or fail to consider the Bank's wishes and interests, especially given the Bank's grip on the controlling shares of MGM. Parretti had relinquished control over MGM. He had also relinquished any expectation that MGM would be run for his benefit or the benefit of other pre-default shareholders. Moreover, Chancellor Allen's "vicinity of insolvency" innovation-while conceptually but perhaps not practically defensible — had no basis in precedent, and none was cited. The Delaware Supreme Court recently rejected Credit Lyonnais' vicinity-of-insolvency Creditor Duty. ${ }^{217}$

210 See id. at 1155.

211 Id. at 1155.

212 Id. at 1155 n. 55.

213 See id. at $1155-56$.

214 See Amir N. Licht, The Maximands of Corporate Governance: A Theory of Values and Cognitive Style, 29 DEL. J. CORP. L. 649, 710 (2004) (noting that Chancellor Allen's discussion of vicinity-of-insolvency fiduciary duties was obiter dictum).

215 Lipson, supra note 87, at 1224 \& n.162 (suggesting that Chancellor Allen's discussion of entity primacy "may be the worst kind of dicta—not simply irrelevant to the holding, but actually contrary to it").

216 Credit Lyonnais, 17 DEL. J. CORP. L. at 1154.

217 See supra note 56 and accompanying text. 
Here, the actual terms of the parties' agreement supply sufficient basis for concluding that Ladd's primary duty was to the Bank. ${ }^{218}$ None of the parties could have expected otherwise, whether the firm was near insolvency or not. An extracontractual insolvency requirement merely increases the creditor's cost of enforcing its contract. ${ }^{219}$ The actual bargain obviated any need for Creditor Duty. With the CGA, no gaps remained to fill.

\section{Blackmore Partners}

Blackmore Partners, L.P. v. Link Energy LLC 220 involved not a corporation but a Delaware limited liability company. ${ }^{221}$ Despite this, the court applied corporate precedents without comment, suggesting that Delaware may take a common approach to these limited liability entities, at least with respect to fiduciary duties. The transaction at issue, along with the Delaware Chancery Court's two-stage resolution of the litigation, nicely illustrates the two main features of contract primacy: the default rule that managers owe primary loyalty to their equity holders and the prospect that equity holders may contract away their default protection to creditors. On its face, the challenged transaction raises an eyebrow. The managers of Link Energy sold the firm's assets in a transaction that paid certain creditors-a group of note holders\$25 million more than the amount of their claims against the firm, but left equity holders with nothing. ${ }^{222}$ The day the details of the deal were announced, the market price of Link equity units dropped from over $\$ 5$ to $\$ 1{ }^{223}$ Plaintiff Blackmore Partners, a holder of equity units whose interest was wiped out in the sale, brought a putative class action against the firm and its board of directors, alleging the board had breached its primary duty to equity holders.

218 Lipson found:

Chancellor Allen's conclusion that the bank was acting in the interests of the entire community seems implausible, if only because the bank was acting antithetically to the expressed desires of one principal shareholder, obviously a member of the corporate community. Rather, consistent with the restructuring agreement, the bank was simply trying to get paid.

Lipson, supra note 87 , at 1224.

219 See supra Part II.E.

220864 A.2d 80 (Del. Ch. 2004) (Blackmore I); 31 DEL. J. CoRP. L. 672 (Del. Ch. 2005) (Blackmore II).

221 Link Energy was also a '34 Act reporting company, whose equity units traded on the OTC Bulletin Board. Link Energy, Annual Report (Form 10-K), at 20 (Jun. 6, 2004).

222 Blackmore II, 31 Del. J. Corp. L. at 676.

223 Id. 
Defendants lost their motion to dismiss in the first reported decision. ${ }^{224}$ Though the complaint failed to allege a conflict of interest or lack of independence of the board, the court held that it was sufficient to allege that the directors approved a transaction that disadvantaged the equity holders. "[N]o transaction could have been worse for the unit holders." 225 The court found it "reasonable to infer . . that a properly motivated board of directors would not have agreed to a proposal that wiped out the value of the common equity and surrendered all of that value to the company's creditors." ${ }^{, 26}$ Under the circumstances, simply alleging that the directors "approved a sale of substantially all of Link's assets and a resultant distribution of proceeds that went exclusively to the company's creditors raises a reasonable inference of disloyalty or intentional misconduct." ${ }^{, 27}$

Ultimately, however, in a second decision, the Chancery Court granted summary judgment to the defendants. ${ }^{228}$ The transaction looks bad on its face, no doubt, overpaying creditors with sale proceeds that should have gone to equity holders. However, a closer examination suggests that the board satisfied whatever duties it owed to equity. The parties had specifically negotiated the relatively unusual governance mechanisms that were in effect at the time the deal, such that board approval of a transaction of the type at issue was plausibly contemplated by the parties.

Link Energy had emerged as the reorganized debtor from the bankruptcy reorganization of EOTT Energy Partners, L.P. The note holders, prebankruptcy creditors of EOTT, had received their notes as part of the reorganization. With their acceptance of the notes, the note holders took a huge reduction in principal as well as a lower interest rate compared to the terms of their prebankruptcy debt claims against EOTT. ${ }^{229}$ They also received 95\% of Link's equity units newly issued under the reorganization plan. To protect themselves going forward, the note holders obtained two important conditions regarding future asset sales. First, the terms of their notes required any purchaser of substantially all of Link's assets to assume the notes. Second, Link's operating agreement authorized its board to approve such a sale without

\footnotetext{
224 Blackmore I, 864 A.2d 80.

$225 I d$. at 86.

226 Id.

227 Id.

228 Blackmore II, 31 DEL. J. CORP. L. at 672.

229 The prebankruptcy debt of $\$ 235$ million at an $11 \%$ interest rate was shaved to $\$ 104$ million at $9 \%$ pursuant to the reorganization plan. Id. at 673.
} 
requiring a vote of the equity. In addition, six of Link's seven directors were appointed by the note holders pursuant to the reorganization plan. In short, the note holders obtained control of the board, the right to demand assumption of their notes by any asset purchaser, and freedom to sell all of the assets without approval of the equity holders. ${ }^{230}$

The court recognized the import of these arrangements. ${ }^{231}$ It held that no enhanced scrutiny of the board's decision was required, since no extraordinary corporate power was being used against the equity class. Under the circumstances, approval of the transaction was routine: "Crucially, the Unit holders, by charter, did not even retain the right to vote on the sale of substantially all of Link's assets. Thus, no extraordinary efforts were needed to secure approval, or to stop a vote, for no such approval or vote was necessary." 232 The court found the board sufficiently disinterested that the business judgment rule applied to insulate the board decision from further scrutiny. $^{233}$

The court also tracked the conventional duty-shifting analysis, thinking it crucial to emphasize the firm's insolvency, which triggered directors' fiduciary duties to creditors. ${ }^{234}$ Despite this homage to the doctrine, it is hard to see what an insolvency requirement adds, except potential litigation costs. Blackmore can be understood as simply a vindication of the parties' agreed

230 Additionally, the Special Committee formed to consider the sale was comprised entirely of directors nominated by note holders. Id at 675 .

231 The court held:

The instrument governing the Notes contained a restrictive covenant requiring any purchaser of substantially all of Link's assets to assume the Notes. The provision was designed to ensure creditors that any such purchaser would honor the Notes, or at least ensure that the Note holders had a seat at the negotiating table in any post-bankruptcy acquisition of Link. In contrast to this power given to the Note holders, the Link operating agreement empowered the Link board of directors to authorize a sale of all or substantially all of Link's assets without a vote of the Unit holders.

Id. at 674 .

$232 I d$. at 681.

233 Id. at 683 . At the very least, a majority of the board approving the transaction was disinterested, as was the Special Committee appointed to consider the transaction. Id. at 684.

234 See id. at 682. The court's fiduciary duty analysis gets murky after that. The court noted that fiduciary duties to creditors did not excuse violations of fiduciary duties to equity holders. $I d$. It articulated the rule that "the board of directors of an insolvent company may take into account the interests of creditors at the apparent expense of stockholders if, in doing so, the board meets its fiduciary duties to all relevant constituencies." Id. It seems hard to know what a director should make of this. 
corporate governance arrangement, ${ }^{235}$ which was far from conventional. Directors were not appointed by the conventional means of equity voting. Equity holders were not afforded their customary right to vote on the sale of the company. Instead, creditor appointees dominated the board, while equity holders were shut out of the sale process. Creditor-appointed directors could be expected to favor their patron's interests. Otherwise, there would be no point to this nonstandard arrangement. Equity holders presumably accounted for these various features in their negotiations over the reorganization plan. The court's refusal to revisit the board's decision respects the parties' deal.

\section{Bargain Should Trump Duty: Abolishing Duty-Shifting Doctrine}

The preceding cases illustrate parties' ability to tailor firms' governance arrangements by contract. The duty-shifting doctrine, however, imposes an additional condition to the parties' bargain. The firm's insolvency is seemingly required before managers may honor their arrangement to favor a creditor over shareholders. But why should this be so? Presumably, the firm's distress is what leads to these governance concessions to the creditor. In any event, the creditor and the firm's management each understand their own interests. The duty-shifting doctrine adds nothing on that score. An insolvency requirement merely increases litigation costs. ${ }^{236}$

To be fair, an insolvency-based doctrine might perform two useful functions, which would be lost if duty-shifting were purely a matter for private contract. First, the absence of a legally mandated duty shift might lead to marginally more overinvestment. There may be firms in distress where no credit contract adequately polices against it. So perhaps existing doctrine could serve as some sort of backstop to private contract? While this approach might deter some incremental amount of overinvestment, it would probably not be worth the costs in terms of manager overcaution, actual litigation, and foregone value-enhancing projects. ${ }^{237}$ Existing duty-shifting doctrine is unlikely to be efficient. I explore this issue more fully in the next section.

Second, an insolvency requirement may preclude managers from selling out to creditors too soon, to the disadvantage of shareholders. That is, an

235 Though not mentioned in Blackmore II, the \$25 million kicker was justified as a payment to note holders for waiving their right to insist that the purchaser assume the notes. According to a company press release, the amount approximated the estimated market premium on the notes had the purchaser assumed them. Blackmore I, 864 A.2d at 83.

236 See supra Part II.E.1.

237 See id. 
insolvency requirement may reduce agency costs of equity. But the business judgment rule offers the right framework for handling this agency cost. ${ }^{238}$ Assuming no management conflict of interest, it is hard to see why managers would give in to creditor demands unless survival of the business required it, ${ }^{239}$ and why this decision would not merit deference as a business judgment. The exigencies of the situation might be useful evidence on managers' motivations. But insolvency makes little sense as a mandatory condition to contract enforcement.

More generally, this issue seems not to be qualitatively different from the generic agency cost question with every transaction: did managers give away too much? That the deal may involve governance features or some measure of managerial control does not change the fundamental question. As noted earlier, every contract commitment of the firm gives away some managerial discretion to pursue future shareholder value. ${ }^{240}$ The framework for evaluating managers' decisions and constraining agency costs of equity should not be different for governance contracts.

Duty-shifting doctrine turns out to be both overinclusive and underinclusive. It offers rights to creditors who have not contracted for them, and it impedes creditors exercising rights for which they have contracted. In both cases, the doctrine is costly. Depending on actual contracts promotes more certainty of application than courts' attempting after the fact to discern the firm's solvency or whether managers failed to act in creditors' best interests. Actual contracts offer arrangements tailored to specific firm conditions. Duty-shifting doctrine should be eliminated.

\section{E. The Efficiency of Private Contract}

Our goal is to minimize the sum of the costs of overinvestment and the costs of preventing it. The costs of Creditor Duty-caution costs, litigation costs, and strong default costs ${ }^{241}$ — have already been discussed.

As for private contract and the level of overinvestment, the prevalence of bank loans for public companies gives some comfort that adequate constraint

\footnotetext{
238 See supra note 166 and accompanying text (explaining the business judgment rule).

239 What would count as a conflict would certainly have to be worked out. Lucrative consulting contracts to old management might qualify, but prolonging the life of the company — and thereby preserving managers' existing jobs-might not.

240 See supra Part III.B.

241 See supra Part II.E.
} 
exists for most public firms. Post-distress adjustment to loan terms is typical. Public companies that hit financial distress almost invariably attempt private renegotiation of their loans. ${ }^{242}$ For the sake of argument, though, let us assume that existing duty-shifting doctrine (or its expansion) prevents some overinvestment that private contracting would not. That parties sometimes contract to head off overinvestment does not prove that they always do. Contracting failure may sometimes occur. Whether this, plus the costs of private contracting, turns out to be more costly overall than Creditor Duty is of course an empirical question. However, there may be good reason to believe that actual contracts are superior to Creditor Duty.

Contracting incurs negotiating and drafting costs, of course, but these are likely to be small. The costs that concern us are not all the costs of writing credit contracts, but only the incremental costs in a world without Creditor Duty. Knowing what we know about delegated monitoring, ${ }^{243}$ we can surmise that credit contracts probably would not change very much if current dutyshifting doctrine were eliminated (or even expanded). Banks and other sophisticated creditors would continue to create their own protection by contract either way. Similarly, unsophisticated creditors would continue to delegate monitoring to sophisticated creditors and, thus, would not themselves contract against borrower overinvestment. Perhaps banks would spend incrementally more on renegotiation to tighten up their protections when a borrower goes into distress. But again, it seems unlikely that banks' contracting practices would be much affected by the presence or absence of duty-shifting doctrine or its expansion. The contours of expanded duties are too vague to substitute for specific contract terms. For similar reasons, bank monitoring costs and practices are not likely to change with any change in Creditor Duty rules.

Caution costs and litigation costs are likely to be significantly lower for private contracts. $^{244}$ Actual contracts have the virtue of fine tailoring,

242 One empirical study found that $92 \%$ of public companies that suffered severe financial distress attempted private workouts. See Stuart C. Gilson et al., Troubled Debt Restructuring: An Empirical Study of Private Reorganization of Firms in Default, 27 J. Fin. ECON. 315, 340 (1990). The sample consisted of 169 publicly traded firms that experienced severe distress during 1978-87. Id.

Where renegotiation fails, the firm enters bankruptcy, where investment decisions receive scrutiny by the court as well as by creditors. See 11 U.S.C. $\$ 363$ (b) (2006) (requiring notice and a hearing before the debtor may use, sell, or lease property of the bankruptcy estate out of the ordinary course of business).

243 See supra Part II.B.

244 Here, I overstate these contract costs. I describe the costs of all contracts generally, as opposed to just the incremental contract costs incurred in a world without Creditor Duty. 
specifying the powers and prohibitions of the parties in a particular context. Managers will know their boundaries much more clearly with private contracts. Moreover, the pool of potential litigants will be much smaller than with Creditor Duty. Not every creditor-in fact, probably only one or a handful — will have rights or standing under an express contract. So litigation and managerial decision costs will be significantly lower.

Costs of foregone transactions will also be comparatively low. To the extent that bank covenants might otherwise squelch a value-enhancing transaction-covenants may not be set perfectly—bank and borrower can negotiate over the specific deal. One important consequence of delegated monitoring is that renegotiation often involves one-stop shopping. The borrower need only make its deal with the bank in order to be able to pursue the efficient investment. So the costs of overinclusiveness with private contracting will be much smaller than for Creditor Duty. ${ }^{245}$ Many fewer efficient deals will founder.

On balance, the costs of Creditor Duty seem likely to dwarf the costs of relying on actual contracts to curb overinvestment. The coverage of actual contracts may be marginally less comprehensive than a Creditor Duty mandate. Overinvestment might be slightly more prevalent. However, on prevention costs, private contract seems superior by a wide margin.

\section{CONCLUSION}

Actual contracts are superior to imagined contracts. Shareholder interests sometimes conflict with those of other corporate constituencies, and managers bent on maximizing shareholder value may sometimes pursue inefficient projects that benefit shareholders but harm other claimants and the firm generally. Expanding managerial fiduciary duties to protect those other claimants, however, is ill-advised. For sophisticated parties, especially those institutionally equipped to monitor the firm, private contract is sufficient to constrain manager opportunism. Expanding fiduciary duty beyond its traditional shareholder-centered focus has no contractual basis and is costly.

I focus on the debt-equity conflict and expanded fiduciary duties for creditors (Creditor Duty). Adopting the standard incomplete contracts approach to corporate fiduciary duties, I show that hypothetical bargain

245 See supra Part II.E.2. 
analysis cannot justify Creditor Duty, either under existing insolvency-based duty-shifting doctrine or proposals for further expansion. Creditor interests are not unitary but varied. Creditors' varying risk preferences and contract protections make a hypothetical multiparty bargain highly implausible. Not all creditors would agree that creditors as a group should enjoy managerial fiduciary duties. It is also far from clear that all credit contracts have gaps, as Creditor Duty proponents must assume. The theory of delegated monitoring explains observed variation in credit contracts. Varying degrees of creditor protection are likely not induced by transaction costs. Even in a world without transaction costs, credit contracts would vary as observed. Finally, Creditor Duty generates costs that likely dwarf the costs of inefficient investment that its proponents fear. With multiple conflicting interests under the same fiduciary umbrella, litigation costs would likely skyrocket. Fear of litigation would trigger increased managerial decision costs and costs in the form of foregone value-enhancing transactions. Instead of the Creditor Duty invitation to ex post judicial intervention, I argue for traditional shareholder primacy and the primacy of contract.

Shareholder primacy should remain the default. It makes sense as a first approximation of the efficient fiduciary rule. Private contracting is likely sufficient to curb overinvestment. Sophisticated bank creditors typically negotiate elaborate covenant protections by the time a firm is in distress. They may even negotiate for control of the firm. Courts should vindicate these private arrangements for creditor primacy without insisting on the firm's insolvency, as the current duty-shifting doctrine demands. That doctrine should be discarded. Given the conceptual and practical infirmities of Creditor Duty, private contracting is superior.

Besides being problematic in its own right, Creditor Duty is perhaps the most visible manifestation of a broader and worrisome trend in corporate law and corporate scholarship: expanding fiduciary duty (Expanded Duty) to address all manner of interclass conflict. To preclude inefficient investment, various Expanded Duty proponents look to embrace conflicting classes of claimants as joint beneficiaries of managerial fiduciary duties. Besides the debt-equity conflict, Expanded Duty has been proposed for common-preferred shareholder conflicts, for example. ${ }^{246}$ And the continuing viability of shareholder primacy has been questioned in light of new conflicts generated by

246 See supra note 5 and accompanying text. 
financial innovation and firms' complex capital structures, chock-a-block with hybrid securities and multiple classes of equity. ${ }^{247}$

While this Article focuses on the fine detail of credit contracts and creditors' relations inter se, I intend in future work to show the generality of Creditor Duty infirmities for the range of Expanded Duty proposals. The basic objection, as elaborated above in the debt-equity context, is threefold. First, the substantive content of the putative Expanded Duty bargain is implausible. Second, contract failure seems unlikely. Third, Expanded Duty is costly.

Similarly, there is no reason to limit contract primacy to creditors and credit contracts. As in the debt-equity context, Expanded Duty generally doubts the efficacy of private contracting. But expanded duties are costly in other Expanded Duty contexts, just as they are in the debt-equity situation. While private contracts may not perfectly constrain managerial opportunism, the cure is likely to be worse than the disease. The costs of that opportunism are likely dwarfed by the costs of bestowing a shared fiduciary duty among conflicting parties. Private bargains should be respected. Parties should be permitted to constrain or modify shareholder primacy by contract. They have sufficient incentive on their own to design careful limits on managerial opportunism.

Expanded Duty implicates broader issues as well. Promoting efficient corporate transactions seems a worthy goal on its face. But interesting boundary issues arise. For example, should non-corporate-e.g., individualtransactions also be subject to efficiency duties? An insolvent individual, for example, has perverse investment incentives similar to those of shareholderfocused corporate managers. ${ }^{248}$ A judgment-proof individual enjoys limited liability of a sort. She may be tempted to pursue risky negative-expected-value investments in order to achieve solvency. Losses will be born by her creditors.

Without a contractual basis, Expanded Duty begins to look like disguised regulation. Regulation is not intrinsically objectionable, of course, but regulatory mandates require justification. Transparency may also matter. To the extent mandated efficiency may be desirable, legislative and regulatory processes exist to focus public discussion and analysis. Creeping corporate fiduciary duty, however, bypasses valuable public process.

\footnotetext{
247 See supra note 6 and accompanying text.

248 See Hu \& Westbrook, supra note 49, at 1389.
} 
